\title{
Archaeological Testing for a Proposed Landfill Expansion (Phase II) City of Del Rio, Val Verde County, Texas
}

Jack D. Eaton

Ronald W. Burkett

Herbert G. Uecker

James T. Abbott

Texas Department of Transportation

Follow this and additional works at: https://scholarworks.sfasu.edu/ita

Part of the American Material Culture Commons, Archaeological Anthropology Commons, Environmental Studies Commons, Other American Studies Commons, Other Arts and Humanities Commons, Other History of Art, Architecture, and Archaeology Commons, and the United States History Commons

Tell us how this article helped you.

This Article is brought to you for free and open access by the Center for Regional Heritage Research at SFA ScholarWorks. It has been accepted for inclusion in Index of Texas Archaeology: Open Access Gray Literature from the Lone Star State by an authorized editor of SFA ScholarWorks. For more information, please contact cdsscholarworks@sfasu.edu. 


\section{Archaeological Testing for a Proposed Landfill Expansion (Phase II) City of Del Rio, Val Verde County, Texas}

\section{Creative Commons License}

\section{(c) (1) \&}

This work is licensed under a Creative Commons Attribution-NonCommercial 4.0 International License 


\section{ARCHAEOLOGICAL TESTING FOR A PROPOSED LANDFILL EXPANSION (PHASE II), CITY OF DEL RIO, VAL VERDE COUNTY, TEXAS}

Jack D. Eaton, Ronald W. Burkett, Herbert G. Uecker, and James T. Abbott

Center for Archaeological Research The University of Texas at San Antonio ${ }^{(B)}$ Archaeological Survey Report, No. 197 
The following information is provided in accordance with the General Rules of Practice and Procedure, Chapter 41.11 (Investigative Reports), Texas Antiquities Committee:

1. Type of investigation: subsurface testing;

2. Project name: Del Rio Landfill (Phase II);

3. County: Val Verde;

4. Principal investigator: Jack D. Eaton

5. Name and location of sponsoring agency: Raba-Kistner Consultants, Inc., 12821 West Golden Lane, San Antonio, Texas 78269, for the City of Del Rio, Texas;

6. Texas Antiquities Committee Permit No. 880;

7. Published by the Center for Archaeological Research, The University of Texas at San Antonio, San Antonio, Texas 78249-0658, 1991.

A list of publications by the Center of Archaeological Research can be obtained by sending $\$ 1.00$ to the Center for Archaeological Research, The University of Texas at San Antonio, San Antonio,Texas 78249-0658. 


\begin{abstract}
During September 1989, a pedestrian survey was conducted within a 105 -acre tract acquired by the City of Del Rio, Val Verde County, for a landfill expansion project. The surface reconnaissance recorded one prehistoric site, $41 \mathrm{VV}$ 1251. As a result, recommendation was made for Phase II subsurface testing.

The Phase II subsurface testing, which included a geomorphic study, was accomplished during February 1990. Cultural resources were recovered indicating presence at site 41 VV 1251 from the Late Paleo-Indian period to the Late Archaic period. However, the site was determined to be almost totally deflated. The geomorphological tests verified this assessment and indicated no deeply buried deposits. Site 41 VV 1251 is not deemed potentially eligible for nomination to the National Register of Historic Places or for designation as a State Archeological Landmark.
\end{abstract}




\section{TABLE OF CONTENTS}

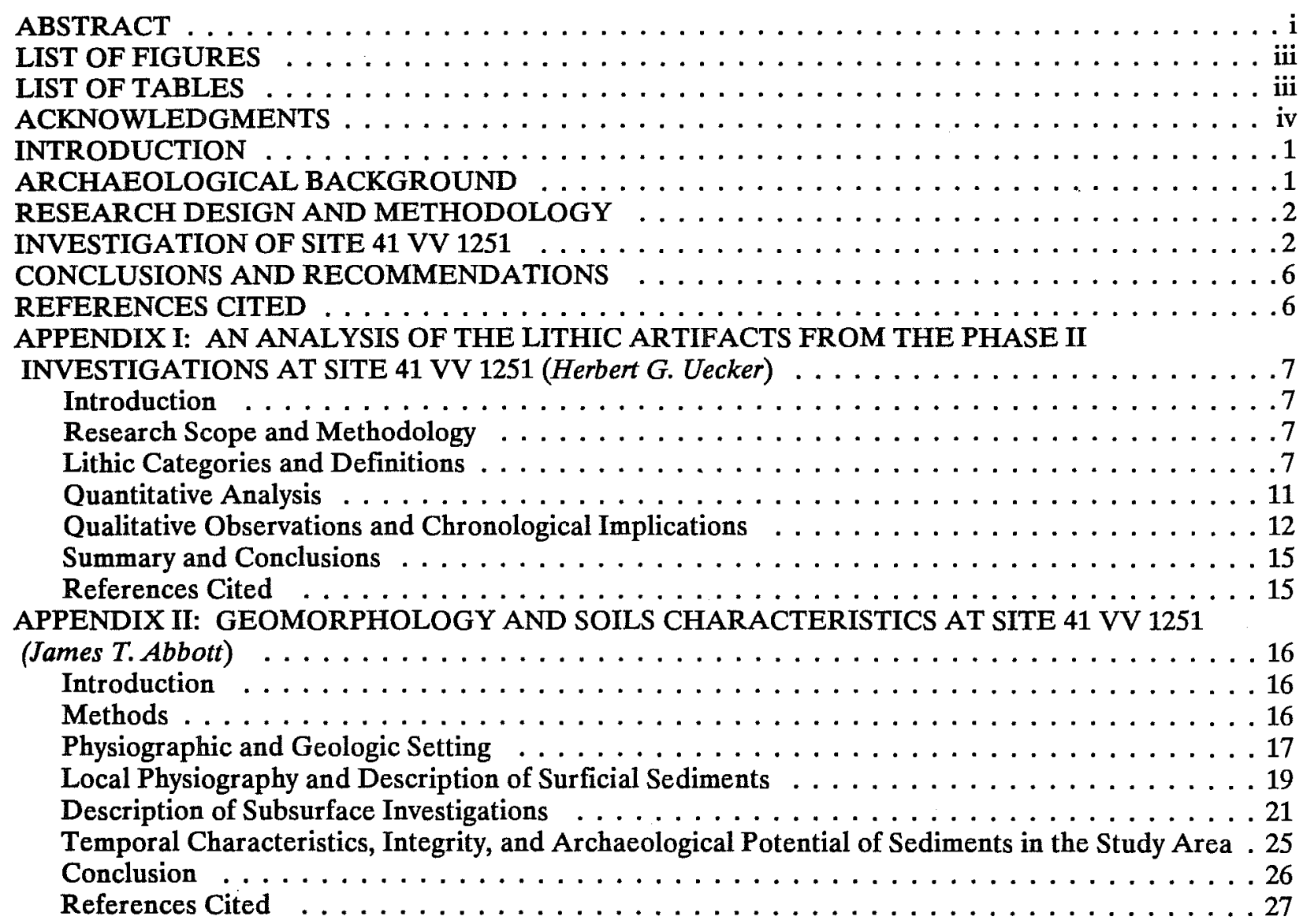




\section{LIST OF FIGURES}

1. Location of the City of Del Rio's Landfill Project Area and Archaeological Site 41 VV $1251 \ldots \ldots$

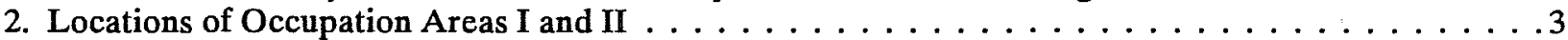

3. Surface Collection Grid, Occupation Area II $\ldots \ldots \ldots \ldots \ldots \ldots \ldots \ldots \ldots$

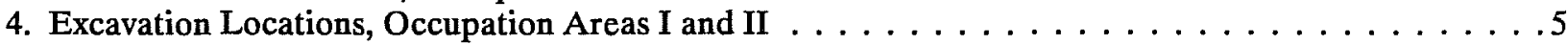

5. Selected Lithic Artifacts from 41 VV $1251 \ldots \ldots \ldots \ldots \ldots$

6. Generalized Distribution of Sediment Types in the Study Area . . . . . . . . . . . . . . 20

7. Generalized Location of Backhoe Trenches in the Study Area . . . . . . . . . . . . . 21

8. Textural and Chemical Characteristics of the Profile Exposed in BHT $1 \ldots \ldots$. . . . . . . . 24

9. Textural and Chemical Characteristics of the Profile Exposed in BHT $5 \ldots \ldots \ldots$

\section{LIST OF TABLES}

1. Lithic Artifacts Excavated from Occupation Areas I and II, 41 VV $1251 \ldots \ldots \ldots$

2. Lithic Artifacts Surface Collected from Occupation Area II, 41 VV $1251 \ldots \ldots \ldots$

3. Lithic Debitage Surface Collected from Occupation Area II, 41 VV $1251 \ldots \ldots$

4. Relative Proportions of Primary, Secondary, and Tertiary Flakes in Lithic Samples from Selected

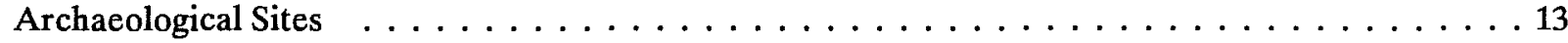

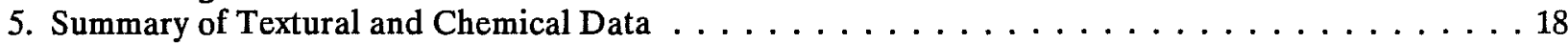

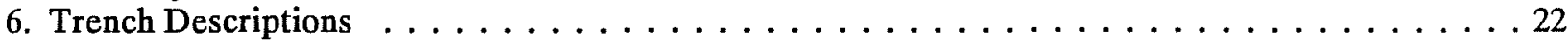




\section{ACKNOWLEDGMENTS}

Thanks are given to the project field staff, Daniel Potter, Maureen Brown, Clinton McKenzie, Herbert Robichaux, and Palma Buttles Valdez, and also to volunteers Fred Valdez, Jr., Curtis Harrell, Helen Harrell, Lyle Sloan, and Jason Sloan. Special thanks are given to James T. Abbott for the geomorphological investigations and to Herbert G. Uecker for his analysis of the collected lithic artifacts.

Thanks are also extended to Clarence Bolner, city engineer, and Jessie Valesquez, and other members of the Del Rio city staff for their time, interest, and information provided. 
This page has been

redacted because it

contains restricted

information. 
Two major physiographic regions meet in southeastern Val Verde County: the Edwards Plateau, just north of Del Rio, and the Rio Grande Plain to the southeast. Three major biotic provinces abut in the Del Rio area: the Balconian to the north and east, the Chihuahuan to the west and south, and the Tamaulipan to the southeast (Blair 1950). The differing physiographic regions and biotic provinces help to define the formation of cultural regions.

Although there is some disagreement on the specifics within cultural regions (Johnson 1986), cultural evolution throughout most of Texas can be presented in a generalized periodic sequence. The Paleo-Indian period is noted by the appearance of the Clovis point tradition ca. 9000 B.C. and continuing until about 6000 B.C. to ca. 2500 B.C.; the Middle Archaic period from 2500 B.C. to 1000 B.C.; the Late Archaic period from ca. 1000 B.C. to 300 B.C.; the transitional Archaic period from 300 B.C. to ca. A.D. 700; and the Late Prehistoric period, A.D. 700 to A.D. 1500, began with the arrival of Europeans. These broad periods generally define changes in subsistence patterns. The chronological markers for these changes are primarily seen in projectile points as they evolved in types and forms through time or as new varieties were introduced. (Specific chronology for the lower Pecos River region will be addressed by Uecker and Abbott in Appendix I and II in this report.)

Some archaeological investigations have been conducted in the vicinity of the landfill project area. An intensive survey was conducted within a portion of the San Felipe Creek watershed just north of Del Rio in 1973 (Prewitt and Dibble 1974). Fourteen sites were recorded, and artifacts ranging from late in the Paleo-Indian period to the Late Prehistoric were recorded. Most of these sites were either deflated or had been disturbed during past landclearing operations. No excavations were carried out beyond minor subsurface probing, and no definitive conclusions were reached. An archaeological survey was conducted within the right-of-way for a proposed water main between San Felipe Springs and Laughlin Air Force Base. This right-of-way extended parallel to Highway 90, roughly $1.5 \mathrm{~km}$ north of the landfill project area (Labadie 1986). One site was recorded near the intersection of Highway 90 and Calaveras Creek. The site was a light scatter of lithic debitage, and shovel testing produced no subsurface cultural materials. (A full description of the landfill study area is presented in Appendix II.)

\section{RESEARCH DESIGN AND METHODOLOGY}

The Phase I surface-collected materials from site $41 \mathrm{VV} 1251$ and the erosional cuts and exposure of what appeared to be remnants of hearth features indicated a prehistoric Indian occupation dating to the Early Archaic period (6000-2500 B.C.). In addition, a Paleo-Indian Clovis point fragment found a short distance outside of the designated landfill area (but on the same geological formation), suggested that the occupation of the site might well extend into the Paleo-Indian period (9000-6000 B.C.). As a result of the brief survey, recommendation was made for further investigations. This would be done to better define the site, establish cultural and chronological information, and determine potential eligibility for nomination to the National Register of Historic Places and State Archeological Landmark status.

The Phase II research design called for mapping the site and establishing a site grid system. Within the grid would be controlled shovel testing to define the actual site area and any concentrations of subsurface cultural materials. At least four $1-\mathrm{m}^{2}$ test units would be excavated in selected places on the site to be expanded in size and number as deemed needed to further explore any features or cultural levels found. At least two backhoe trenches would be dug in selected places to document any deeply buried deposits. In addition, a geomorphologist would join the field team to deeply trench as needed to examine the soil formation and collect samples for analysis. Standard archaeological techniques were used in the investigation, and all excavated earth was screened for retention of cultural materials.

\section{INVESTIGATION OF SITE 41 VV 1251}

Upon arrival at the site, three $1-\mathrm{m}$ test excavations were begun at predetermined locations; the backhoe was assigned directly to the geomorphologist; a datum point was selected; and a base line was established.

A half-day into the project, the geomorphologist was able to determine that the " $\mathrm{A}$ " horizon was thin to nonexistent and that the " $B$ " horizon could be tentatively dated to no later than the Pleistocene. Shovel testing determined lithic debitage was either on the surface or so close that no stratification was evident. Closer examination led to the conclusion that the artifacts being found were resting on or just above the easily recognizable " $B$ " horizon. This was 
in line with the tentative geomorphologist date for the " $B$ " horizon.

At this point, the decision was made to forego the normal 1-m depth for testing and, instead to limit the depth to $10 \mathrm{~cm}$ into the " $B$ " horizon regardless of the ambient depth of the test unit. It was felt that this approach would provide for much greater coverage and increase the chance of finding stratified deposits. Nineteen test units were completed in this manner. No cultural stratification was evidenced. The presumption that deposits would be above the "B" horizon continued to be borne out. Geomorphological testing continued until five trenches had been dug to a depth of $1-1 / 2$ to $2 \mathrm{~m}$. No cultural remains were noted.

As a result of the Phase I survey and testing during the current study, two areas of site 41 VV 1251 appeared to have relative concentration of artifacts. There were designated Occupation Areas I and II (Fig. 2).

Emphasis was shifted from subsurface testing, with its disappointing results to acquiring a comprehensive surface collection. A grid was laid out in Occupation Area II (Fig. 3). Personnel were placed at $2-\mathrm{m}$ intervals, and fifty $25 \times 30 \mathrm{~m}^{2}$ were surface collected. All lithic artifacts and debitage were bagged by square, a total of some $37,500 \mathrm{~m}^{2}$. These artifacts have been analyzed by Uecker (see Appendix I). Note that a Golondrina point found in square Y4 and a Lerma point from Y21 are evidence of a Late Paleo-Indian occupation. All other diagnostic artifacts appear to be Early Archaic. The heaviest occupation was between Y3/Y4 on the northeast and Y29/Y30 on the southwest. Nothing was found in the peripheral squares. Based on the numbers of spent shotgun shells on the ground in varying stages of decomposition, it can be assumed that over the years many of the dart points that might have been in this area were picked up by hunters.

When the backhoe was made available after geomorphic testing was completed, it was utilized in Occupation Area I (Fig. 4) for gross excavation. Although shovel testing had been without results, this area still showed potential (see Phase I survey report; Burkett 1990). Two trenches were dug, $1 / 2 \mathrm{~m}$ deep, $35 \mathrm{~m}$ long. A few pieces of burned limestone and a finely worked uniface tool were found in the backdirt, but no features could be identified. Using the blade/scoop end of the backhoe, approximately 60 linear $\mathrm{m}$ by $1 \mathrm{~m}$ in width were taken down a few centimeters at a time. What

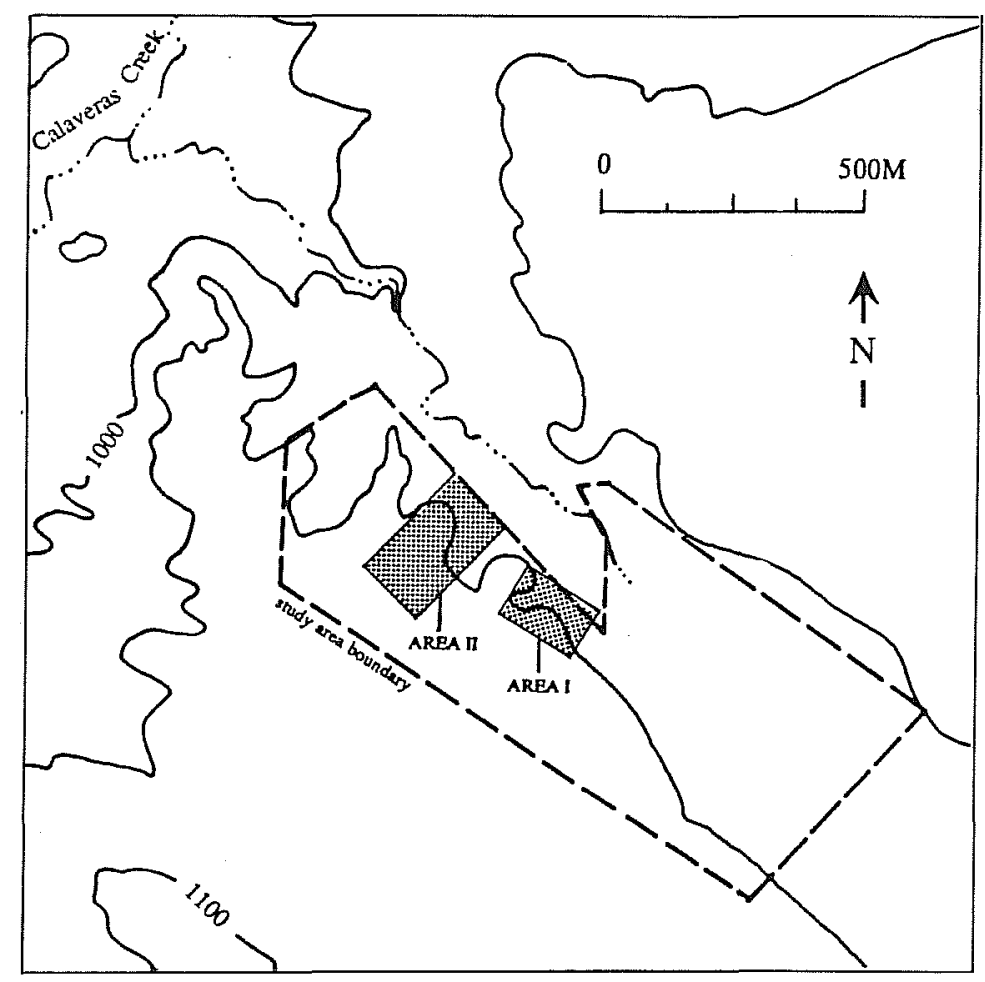

Figure 2. Location of Occupation Areas I and II. 


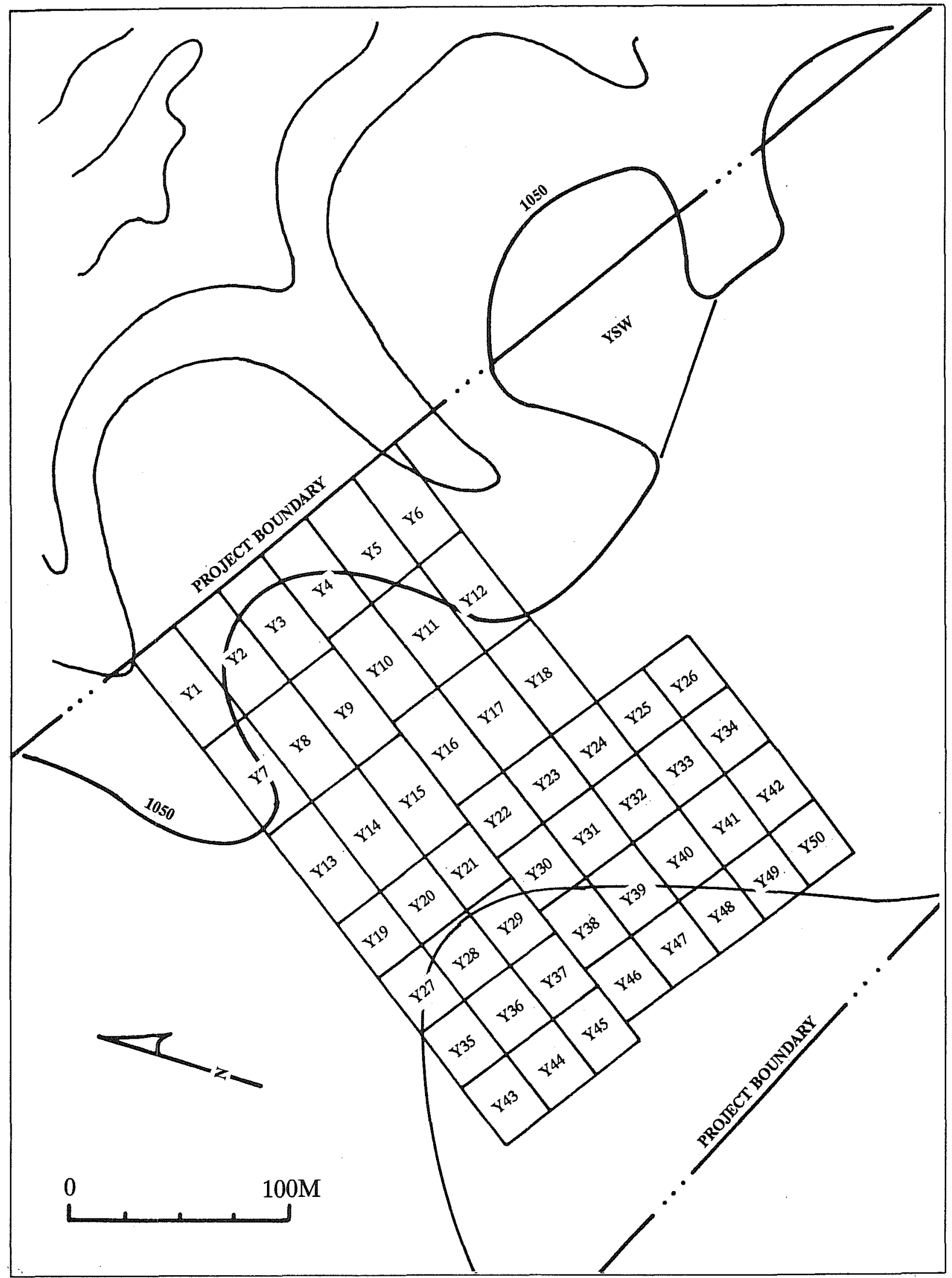

Figure 3. Surface Collection Grid, Occupation Area II. 


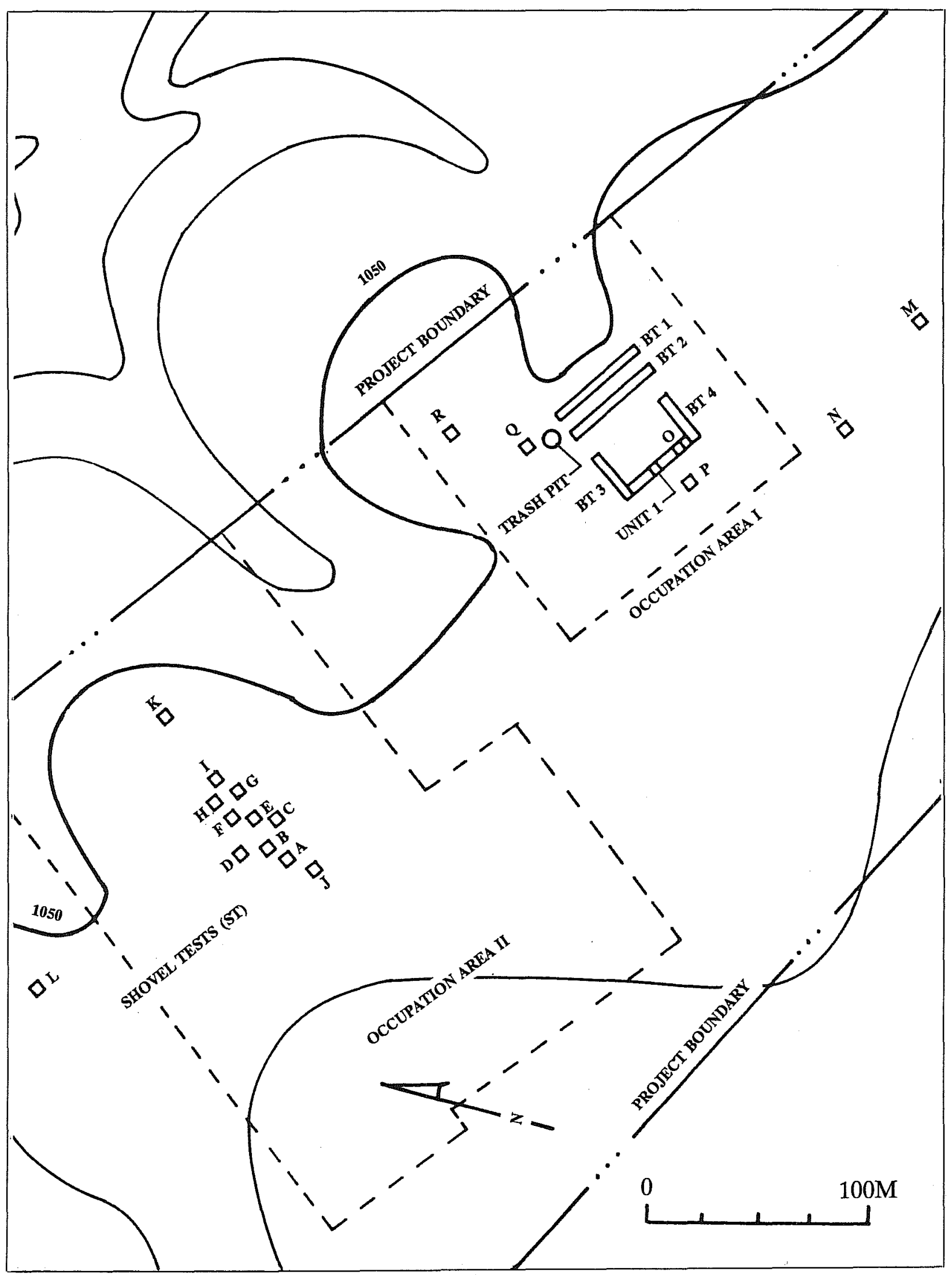

Figure 4. Excavation Locations, Occupation Areas I and II. 
appeared to be burned rock was exposed at what became Unit 1 . Unit $1,1.5 \times 1.5 \mathrm{~m}$, contained the remnants of what might have been two small hearths set into the " $B$ " horizon. Two chert flakes were associated with the feature, neither of them burned. No evidence of a pit was apparent when the features were bisected. Therefore, the results were inconclusive.

\section{CONCLUSIONS AND RECOMMENDATIONS}

Archaeological investigations at site 41 VV 1251 within the Del Rio proposed landfill area have indicated presence at the site from the Late Paleo-Indian period to the Late Archaic period. This was evidenced by the projectile point types identified from controlled surface collections and subsurface testing. However, extensive testing demonstrated that the site is almost totally deflated. Past natural and artificial surface disturbances have nearly obliterated all cultural deposits over much of the site. This was additionally verified by geomorphic backhoe tests that also indicated no deeply buried cultural strata.

The surface collections and testing have, in effect, mitigated the thin cultural resource. We deem that since little more significant information can be extracted from site 41 VV 1251, no further work is recommended.

Site $41 \mathrm{VV} 1251$ is not considered potentially eligible for nomination to the National Register of Historic Places or for designation as a State Archeological Landmark.

\section{REFERENCES CITED}

Blair, F. W.

1950 The Biotic Provinces of Texas. The Texas Journal of Science 2:93-117.

Burkett, R. W.

1990 Archaeological Survey (Phase I) for Proposed Landfill Expansion, City of Del Rio, Val Verde County, Texas. Center for Archaeological Research, The University of Texas at San Antonio, Archaeological Survey Report 193.
Epstein, J. F., T. R. Hester, and C. Graves

1980 Papers on the Prehistory of Northeastern Mexico and Adjacent Texas. Center for Archaeological Research, The University of Texas at San Antonio, Special Report 9.

Hester, T. R.

1980 Digging Into South Texas Prehistory. Corona Publishing Company, San Antonio, Texas.

Johnson, L., Jr.

1986 A Plague of Phases: Recent Sociocultural Taxonomy in Texas Archeology. Bulletin of the Texas Archeological Society 57:1-26.

Labadie, J. H.

1986 An Archaeological Survey of a Proposed Water Main in Val Verde County, Texas. Center for Archaeological Research, The University of Texas at San Antonio, Archaeological Survey Report 158.

Prewitt, E. R.

1981 Cultural Chronology in Central Texas. Bulletin of the Texas Archeological Society 52:65-89.

Prewitt, E. R. and D. S. Dibble

1974 The San Felipe Creek Watershed Project, Val Verde County, Texas: An Archeological Survey. The University of Texas at Austin, Texas Archeological Survey Report 40.

Turpin, S.

1984 Prehistory in the Lower Pecos Region: An Overview. The University of Texas at Austin, Texas Archeological Survey Report 90.

Weir, F. A.

1976 The Central Texas Archaic. Unpublished Ph.D. Dissertation, Department of Anthropology, Washington State University, Pullman. 


\title{
APPENDIX I: AN ANALYSIS OF LITHIC ARTIFACTS FROM THE PHASE II INVESTIGATIONS AT SITE 41 VV 1251
}

\author{
by Herbert G. Uecker
}

\section{INTRODUCTION}

Both quantitative and qualitative results of an examination of 337 lithic artifacts from site $41 \mathrm{VV} 1251$ in Val Verde County near the city of Del Rio are presented. The lithic analysis was done at the CAR-UTSA laboratory in June 1990. The assistance of Thomas $R$. Hester of the Texas Archeological Research Laboratory in Austin, who provided references and information on the current state of the art of lithic analysis, is gratefully acknowledged. Confirmation by Thomas C. Kelly of San Antonio of the author's classification of the Lerma projectile point is also greatly appreciated.

\section{RESEARCH SCOPE AND METHODOLOGY}

In general, lithic analyses from archaeological sites in Texas, and those pertinent to the Lower Pecos Cultural Region in particular, for the most part have utilized one or more of the following formats (Hester, personal communication): (1) the production and presentation of comprehensive numerical/ typological tables; (2) chronological analyses based on vertical stratigraphy and associated distributions of diagnostic artifacts or surface finds of diagnostics, or similar criteria; (3) intrasite activity area analyses based on horizontal distributions and associations of both diagnostics and debitage;(4) lithic reduction stage and/or technological analyses based on overall ratios of primary, secondary, and tertiary flakes, numbers and proveniences of tools and diagnostics in the sample; and (5) exacting typological/functional descriptions and analyses based on detailed measurements and examinations of diagnostics and tools or other specialized techniques such as microscopic edge ware studies.

The valid application of most of these methods to the lithic sample from 41 VV 1251 was precluded by several factors. Much of the site had been subjected to both natural and artificial disturbances which virtually destroyed all primary cultural deposits there. Natural deflation resulted from extensive colluvial or "sheet" erosion, highly localized alluvial activity, microscarping, and soil turbation (see Appendix II for detailed descriptions of these and other geomorphological processes which are known to have impacted the site).
Small-scale modern construction activities within the proposed landfill improvement site, such as the construction of the water tank and dam near the eastern edge of the property, have also occurred. In addition to being skewed by disturbances, the sample was too small to be statistically definitive.

The current analysis was confined to the production of Tables 1-3 and some brief comments on the lithic technology based very loosely on an examination of the debitage and on the chronology based on diagnostic artifacts. Table 1 lists the lithic artifacts recovered from shovel tests and backhoe trenches in Occupation Areas I and II. Tables 2 lists the lithic materials from controlled surface collections for Occupation Area II, and Table 3 lists the lithic debitage recovered from Occupation Area II. (See the bottom of Table 1, Lithic Classification System, for a list of artifact codes that were adapted for this project as an aid in presenting the data in Tables 1-3.)

\section{LITHIC CATEGORIES AND DEFINITIONS}

The following definitions were employed in the analysis of the lithics. With the exception of burned chert, the definitions were derived or adapted from Crabtree (1972), Mallouf (1976), and Shafer (1969).

Core-A nodule, pebble, cobble, or slab from which a flake or flakes has been intentionally removed.

Flake-A piece struck from a core retaining all or part of the striking platform utilized for their removal.

Primary Flake - A flake retaining cortex over its entire external or dorsal surface. A primary flake results from initial testing and/or decortification of a core. As defined in this study, a primary flake may have a striking platform devoid of cortex.

Secondary Flake-A flake retaining from 1 to $99 \%$ cortex on its external or dorsal surface as a result of having been struck from a partially decorticate core.

Tertiary Flake-A flake devoid of cortex on the external or dorsal surface, including the striking platform.

Cortex Platform Flake-A flake with a platform of unmodified weathered cortex. Because of platform cortex, such flakes are classified as secondary flakes. 
TABLE 1. LITHIC ARTIFACTS EXCAVATED FROM OCCUPATION AREAS I AND II, 41 VV 1251

\begin{tabular}{|c|c|c|c|c|c|c|c|c|c|c|c|c|c|c|c|c|}
\hline & D2C & D2S & D2L & D3s & D3M & D3L & D3B & DST & DEP & DTD & D 9 & BM2D & BT2U & U1 & U3W & TOTAL \\
\hline ST A & 1 & & & & & & 1 & & & & & & & & & 2 \\
\hline ST B & & & & & & & & & & & & & 1 & & & 1 \\
\hline ST J & 1 & 1 & & 1 & 1 & & & & 1 & 2 & & & 1 & & & 8 \\
\hline ST K & & 1 & 1 & 1 & & & 2 & & 1 & 2 & & & 1 & & & 9 \\
\hline ST N & & & & & & & 1 & & & 1 & & 1 & & & & 3 \\
\hline STO & & & & & & & 1 & & & & & & & & & 1 \\
\hline ST P & & 1 & & 1 & & & & 1 & & 2 & & & & & & 5 \\
\hline U 1 & & & & & & 1 & & & & 1 & & & & & & 2 \\
\hline BT I & 2 & 2 & & & 1 & & & & & & 1 & & 1 & 1 & 1 & 9 \\
\hline TOTAL & 4 & 5 & 1 & 3 & 2 & 1 & 5 & 1 & 2 & 8 & 1 & 1 & 4 & 1 & 1 & 40 \\
\hline
\end{tabular}

\section{LITHIC CLASSIFICATION SYSTEM}

I. Cores

II. Debitage

A. Primary flakes

a. Single-faceted platform

b. Small multifroeted plattorm

c. Large multifnceted plattorm

B. Secondary flakes

a. Cortex platform

b. Single-faceted platform

c. Small multitaceted plattorm

d. Large multifaceted plattorm

e. Bitace thinning flake

C. Blades

a. Primary

b. Secondary

c. Tertiary

D. Modified Debitage
a. Primary
b. Secondary
c. Tertiary

E. Modified Debitage (trimmed)
a. Primary
b. Secondary
c. Tertiary

F. Chips
a. Corticate
b. Decorticate

G. Chunks
a. Corticate
b. Decorticate

H. Burned Chert

ARTTFA T
C
D
D1
D1S
D1M
D1L
D2
D2C
D2S
D2M
D2L
D2B
D4
D4P
D4S
D4T
D5
D5P
D5S
D5T
D6
D6P
D6S
D6T
D7
D7C
D7D
D8
D5

D8

D8C

D8D

D9
III. Bifaces

A. Dart points
a. Baker
b. Golondrina
c. Gower
d. Lema
c. Nolar
L. Pandale
g. Tortugas
h. Unidentified

B. Arrow points

a. Unidentified

C. Miscellaneous Thin

a. Preforms

b. Fragments

1. Proximal

2. Medial

3. Distal

4. Lateral

5. Unidentified

D. Miscellaneous Thick

a. Whole

b. Fragments

1. Proxims

2. Medial

3. Distal

4. Lateral

5. Unidentified

IV. Unifaces

A. Clear Fork

B. Miscellaneous Thin

a. Whole

b. Fragments

c. Miscellaneous Thick

a. Whole

b. Fragments
B

BD

BD1

BD2

BD3

BD4

BD5

BD6

BD7

BD8

BA

BA1

BM

BM1

BM2

BM2P

BM2M

BM2D

BM2L.

BM2U

BT

BTI

BT2

BT2P

BT2M

BT2D

BT2L

BT2U

U

U1

U2

U2W

U2F

U3

U3W

U3F 
TABLE 2. LITHIC ARTIFACTS SURFACE COLLECTED FROM OCCUPATION AREA II, 41 VV 1251

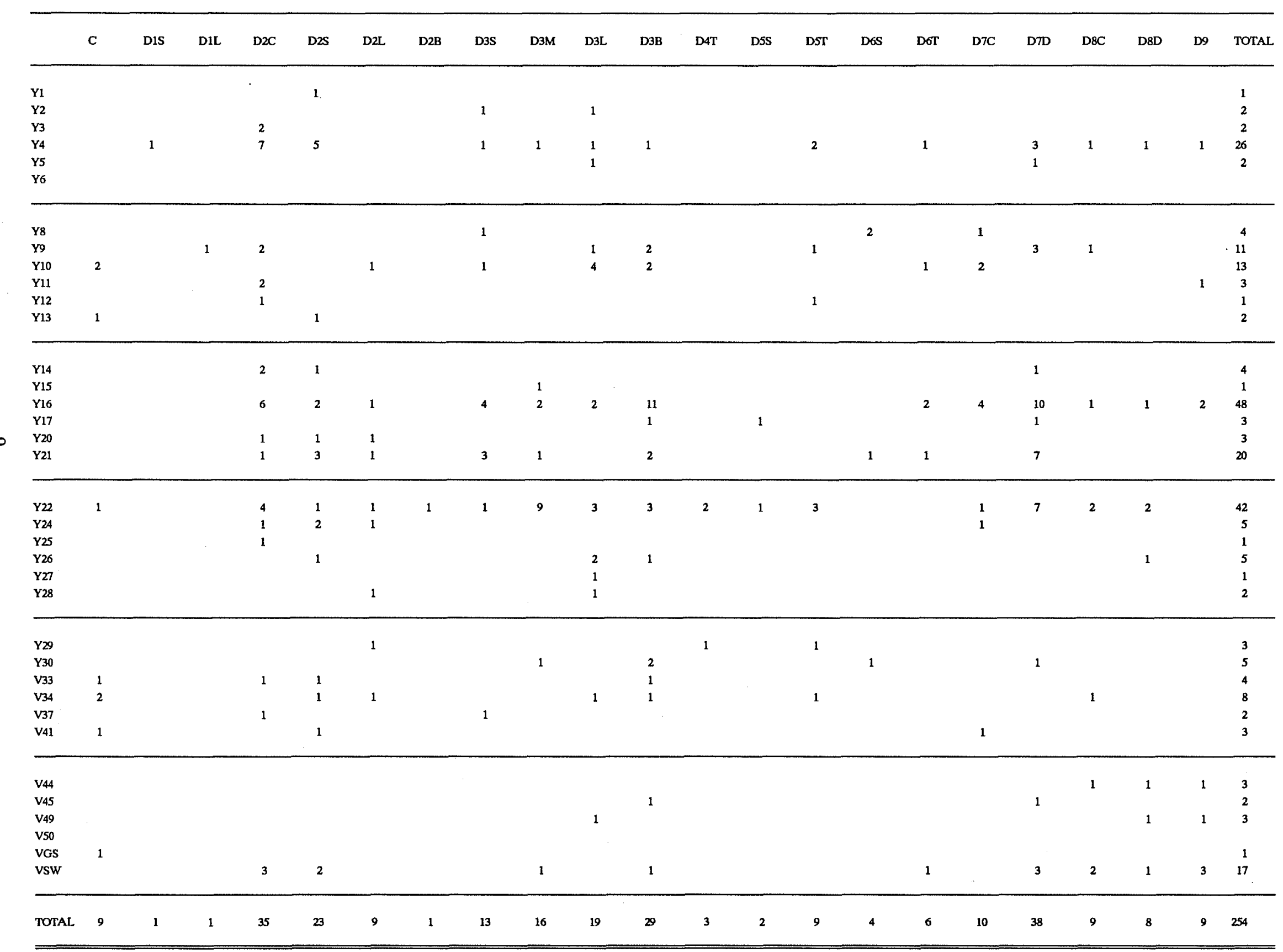


TABLE 3. LITHIC DEBITAGE SURFACE COLLECTED FROM OCCUPATION AREA II, 41 VV 1251

\begin{tabular}{|c|c|c|c|c|c|c|c|c|c|c|c|c|c|c|c|c|c|c|c|c|}
\hline & BD1 & BD2 & BD3 & BDA & BDS & BD6 & BD7 & BD8 & BA1 & BM1 & BM2P & BM2M & BM2D & BM2U & BTI & BT2P & BT2U & usw & U3W & TOTAL \\
\hline Y1 & & & & & & & & & & & & & & & 1 & & & & & 1 \\
\hline Y2 & & & & & & & & & & & 1 & & & & & & & & & 1 \\
\hline$Y_{3}$ & & & & & & & & & & & & 1 & & & & 1 & & & & 2 \\
\hline$Y_{4}$ & & 1 & & & & & & & & 1 & & & & & 1 & & 1 & & & 4 \\
\hline Y5 & & & & & & & & & & & & & 2 & & . & & & & & 2 \\
\hline Y6 & & & & & & & & & & & & & & & & & & 1 & & 1 \\
\hline Y8 & & & & & & & & & & & & & & & & 1 & & & & 1 \\
\hline Y9 & & & & & & & & & & & 1 & & & & 1 & & 2 & & 2 & 6 \\
\hline Y10 & & & & & & & & & & & & 2 & & & & & & & & 2 \\
\hline \\
\hline \multicolumn{21}{|l|}{ Y12 } \\
\hline $\mathrm{Y} 13$ & & & & & & & & & & & & & & & & & & & & \\
\hline \multicolumn{21}{|l|}{ Y14 } \\
\hline Y15 & & & & & & & & 1 & & 1 & & & & 1 & & & & & & 3 \\
\hline Y16 & 1 & & & & & & & 1 & & & & & & & & & & & & 2 \\
\hline \multicolumn{21}{|l|}{ Y17 } \\
\hline Y2O & & & & & 2 & & & & & & & & & & & & & & & 2 \\
\hline Y21 & & & & 1 & & & & & & & 1 & & & & & 1 & & & & 3 \\
\hline Y22 & & & & & & & 1 & & & & & & & & & & 1 & & & 2 \\
\hline \multicolumn{21}{|l|}{ Y24 } \\
\hline Y25 & & & & & & & & & & & & & & & & & 1 & & & 1 \\
\hline \multicolumn{21}{|l|}{ Y26 } \\
\hline \multicolumn{21}{|l|}{ Y27 } \\
\hline \multicolumn{21}{|l|}{ Y28 } \\
\hline \multicolumn{21}{|l|}{$\mathrm{Y} 29$} \\
\hline \multicolumn{21}{|l|}{ Y30 } \\
\hline V33 & & & & & & 1 & & & & & & & & & & & & & & 1 \\
\hline V34 & & & 1 & & & & & & & & & & & & & & & & & 1 \\
\hline \multicolumn{21}{|l|}{ v37 } \\
\hline \multicolumn{21}{|l|}{ V41 } \\
\hline \multirow{2}{*}{\multicolumn{21}{|c|}{$\begin{array}{l}\text { V44 } \\
\text { V45 }\end{array}$}} \\
\hline & & & & & & & & & & & & & & & & & & & & \\
\hline$V_{49}$ & & & & & & & & & & 1 & & & & & & & & & & 1 \\
\hline v50 & & & & & & 1 & & & & & & & & & & & & & & 1 \\
\hline VGS & & & & & & & & & & & 1 & & & & & & 1 & & & 2 \\
\hline vsw & & & & & & & & & 1 & & & 1 & 1 & & 1 & & & & & 4 \\
\hline TOTAL & 1 & 1 & 1 & 1 & 2 & 2 & 1 & 2 & 1 & 3 & 4 & 4 & 3 & 1 & 4 & 3 & 6 & 1 & 2 & 43 \\
\hline
\end{tabular}


Single-Faceted Platform Flake - A flake with a platform consisting of a single removal scar (facet) produced by previous flaking.

Multifaceted Platform Flake-A flake with a platform consisting of two or more facets produced by previous knapping. These flakes can be further subdivided into small $(<1 \mathrm{~cm})$ and large $(>1 \mathrm{~cm})$ according to the width of the combined facets.

Biface Thinning-Flake-Typically, these flakes have multifaceted, lenticular-shaped striking platforms and a characteristic lip or ridge which is at right angles to the axis of removal on the ventral side. The striking platforms are bifacially prepared and multifaceted. The dorsal side of the flake is multifaceted and rarely exhibits cortex.

Blade Flakes - A flake with parallel or subparallel lateral edges; the length being equal to, or more than, twice the width. One or more parallel ridges or scars run nearly the length of the dorsal surface. Cross sections are plano-convex, triangulate, subtriangulate, rectangular or trapezoidal. Blade flakes are associated with prepared core and blade techniques; not a random flake.

Chip-A portion of a flake which due to breakage, crushing or shattering has no platform. Chips may be further subdivided into corticate and decorticate.

Chunk-Fragment with or without cortex showing no striking platform and no force rings (bulbs of percussion) emanating from the direction of applied force. Thickness approaches maximum length and width. A chunk is too small to be a core, too large and massive to qualify as a chip. Chunks may be further subdivided into corticate and decorticate.

Burned Chert-Any piece of chert or flint exhibiting any or all of the following: obvious discoloration (usually blackening, graying, or reddening), mottling, cracking, or surface erosion or roughening (usually fine textured) which is readily attributable to either direct or indirect heating. In this study, burned chert artifacts were first classified and counted whenever possible by general type such as flake, chip, etc., and then counted a second time under the burned chert category. The burned chert category was not further subdivided.

Modified Flake or Chip-A flake or chip that may have been used as a tool. Such use is evidenced by minute nicking, battering, or sheen along the edges of the flake or chip.

Trimmed Flake - A flake or chip demonstrating intentional edge preparation through removal of a uniform series of tiny flakes. A trimmed flake is distinguished from modified flakes and chips in that human alteration of the piece is unquestionable (Mallouf 1976).

Biface - An artifact or artifact fragment bearing flake scars on both faces.

Uniface-An artifact or artifact fragment bearing flake scars on only one face. A uniface is distinguished from a modified flake or chip in that the unifacial flaking was directed at the overall shaping of the artifact as well as creating a working edge.

\section{QUANTITATIVE ANALYSIS}

Table 1 presents the lithics recovered in Occupation Areas I and II during the shovel testing and backhoe test trenching operations, and Tables 2 and 3 present the lithics from the controlled surface collection at Occupation Area II. Precise quantitative interpretations and comparisons of lithics, either within or between samples or sites, should be made with some reservations. Given samples probably never represent pure or even highly viable statistical universes because of the impact of various agents. Natural and artificial alterations of landscapes such as those at 41 VV 1251, including soil erosion, animal burrowing, livestock activities, collecting of artifacts by landowners, ranch hands, guests, and trespassers almost always have taken place in archaeological sites prior to their discovery and documentation by archaeologists. Also, even the most experienced archaeologists will fail to spot some artifacts during surface surveys, or there may be a subliminal tendency to collect certain types of artifacts and ignore others. Likewise, test excavations are inherently very limited. Thus, samples will be biased, and any analyses of them by standard statistical means will necessarily be somewhat inaccurate.

Nevertheless, when large enough samples have been obtained by what are fairly uniform survey or excavation methods, archaeologists will often attempt to do a quantitative analysis of the sample and compare it with samples from other sites. Unfortunately, the lithic sample from 41 VV 1251 totaled only 297 surface-collected specimens (Occupation Area II) and 40 excavated specimens (Occupation Areas I and II). Yet even given such a nominal sample, certain broad comparisons can be made between the quantitative data from $41 \mathrm{VV} 1251$ and those from other prehistoric archaeological sites.

For example, a percentage comparison of primary to secondary to tertiary flakes within the surface-collected portion of the sample from 
41 VV 1251 yields the proportion 1.33-45.33$53.33 \%$. Compatible data have been generated for lithic samples from similar prehistoric sites. Proportions of the same categories were calculated for a sample of lithics containing 3900 specimens excavated from a 1- x 1-m unit at site 41 BX 228, a stratified burned rock midden site extensively test excavated by the CAR-UTSA in 1979 (Black and McGraw 1985). The comparison for the flakes from 41 BX 228 was 0.93-19.32-79.75\%. Analogous categories from excavations at two central Texas sites are shown in Table 4.

Generally, the calculation and comparison of these types of quantitative data on various categories of lithics from archaeological sites in Texas and elsewhere have been in vogue among archaeological scholars for quite some time, perhaps throughout the last several decades. Some of the ostensible objectives of such comparisons have been to distinguish the types and levels of lithic technologies which were being utilized at various kinds of sites over time and to discern intrasite activity areas. Given such knowledge, it might eventually be possible to derive a viable range of generally applicable or generic site functions or types. Also, it might eventually be possible from these kinds of analyses to define optimum sample size more precisely and thus determine the most efficient methods of surveying and testing various kinds of sites. The degree of attainment of such objectives to date is an open proposition, and it seems likely that archaeologists are still in the early phases of perfecting techniques of lithic analysis and viable applications of the resulting information.

\section{QUALITATIVE OBSERVATIONS AND CHRONOLOGICAL IMPLICATIONS}

All phases of lithic technology, with the possible exception of local procurement of raw materials, were engaged in by prehistoric peoples at $41 \mathrm{VV}$ 1251. This is evidenced by the presence of several hundred pieces of debitage, including cores and reduction flakes and chips which represent the initial and secondary stages of both unifacial and bifacial tool manufacture. There are also several specimens of the finished unifacial and bifacial tools which are tertiary stage end products. From the number of only slightly modified and/or trimmed flakes in the sample, a significant amount of casual tool manufacture and usage occurred there.

The only silicate rock (the chert from which the tools are generally fashioned) known to occur near the site is very sparsely distributed as clasts within a natural deposit of Pliocene to Pleistocene age.
The deposit is the Uvalde Gravel formation (see Appendix II for a detailed description of the morphology, age, and environment of the formation of the Uvalde Gravel) which caps the uplands near the site. However, the siliceous material from the local deposit is completely inadequate for tool manufacture. Drainages in the area contain few chert cobbles of sufficient size and quality for knapping (Burkett, personal communication). Therefore, the sources of usable lithics exploited by the prehistoric inhabitants of the site in particular and the area in general are unknown. Perhaps the proportionately low percentage of primary flakes found at the site is evidence that not much first stage reduction was done there due to the inconvenient distance to raw materials. The presence of the proximal end of a Gower dart point within the sample that was formed from what seems to be volcanic pumice or solidified tuff, may be further evidence of the local scarcity of lithic materials more suitable for tool manufacture. At any rate, several of the cores in the sample are obviously from well-rounded stream gravels, wherever their natural provenience may have been.

With the exception of the piece of igneous material, the stone used for tools appears to have been generally of acceptable quality for working, and there is little visible evidence that heat alteration was used as an integral or prerequisite part of the reduction or tool-manufacturing processes. Most of the heat alteration observed seemed to have occurred fortuitously, apparently when artifacts were discarded near fires. It is also possible that some or all of the heat alteration seen on the artifacts was a result of either natural or man-made fires.

The prehistoric peoples of the Lower Pecos Region, like those in much of Texas, practiced a stone age hunting and gathering lifeway throughout most of their period of cultural evolution. Thus, the production of lithic tools and the technologies associated with their production are major facets of prehistoric lifeways in general and particularly of ancient subsistence patterns. Several key site excavations in the Lower Pecos Region during the 1960s helped establish the cultural and technological sequence for the region in general and for Val Verde County in particular.

Johnson (1964) was perhaps the first to propose a generalized projectile point sequence for the region. It is based on excavations at the Devil's Mouth site in Val Verde County and includes a Late Paleo-Indian cultural period (ca. 8000 to 5000 B.C.), and the Early (ca. 5000 to 3000 B.C.), Middle (ca. 3000 to 2500 B.C.), and Late (ca. 2500 B.C. to 1000 A.D. or later) Archaic periods. Apparently Johnson 
TABLE 4. RELATIVE PROPORTIONS OF PRIMARY, SECONDARY, AND TERTIARY FLAKES IN LITHIC SAMPLES FROM SELECTED ARCHAEOLOGICAL SITES

Site Number (year excavated) and Reference
Relative Percentages of Primary, Secondary, and Tertiary Flakes
41 BX 271 (1974);

Jones, Foster, and Kunert (1979)

41 BX 271 (1979);

Jones, Foster, and Kunert (1979)

$41 \mathrm{KE} 49$ (unknown);

Kelly (1975)
7 to 20 to 73

5 to 20 to 75

9 to 21 to 70 considered the use of the bow and arrow as a Late Archaic trait since he did not distinguish a Neo-American or Late Prehistoric period for the Lower Pecos Region. Shafer (1986:130) has recently provided a comprehensive and up-to-date projectile point sequence for the region.

Also in the mid-1960s, Dibble and Lorrain (1968) excavated the Bonfire Shelter site in Val Verde County. Bonfire Shelter is a faunal jump-kill site which contained the skeletal remains of extinct bison and elephant in association with Plainview and Folsom (Turner and Hester 1985:99, 142) projectile points. The radiocarbon analysis from the site's bison kills dated to around 8200 B.C. (Hester 1980:132). Word and Douglas (1970) excavated at the Baker Cave site (41 VV 213) between 1962 and 1966. Baker Cave contains cultural deposits which apparently date from about 7000 B.C. to 1000 A.D. or later (Hester 1980:86). Additional excavations were performed there by the Witte Museum of San Antonio and the CAR-UTSA in 1984 and 1986.

From the time of those seminal excavations in the 1960s to the present, much additional survey and excavation work has been done in the Lower Pecos Region. Most recently, Shafer (1986) has compiled and presented comprehensive paleoclimatological and cultural sequences for the Lower Pecos Region, which include detailed descriptions of the evolution of the lithic technologies used there. Shafer's recent data is far too voluminous to summarize in this report; therefore, the interested reader is referred directly to his work. Attesting to the rich potential of the Lower Pecos Region, Shafer (1986:65) estimates that there are over 3000 archaeological sites in the area near the mouth of the Pecos River alone. At the time of preparation of this report, almost 1300 archaeological sites in Val Verde County had been officially recorded with the
Texas Archeological Research Laboratory in Austin.

Projectile points and tools recovered would tend to indicate a general range of occupation at site 41 VV 1251 of perhaps 7000 B.C. to 1000 A.D. or slightly later. Classic specimens of diagnostic projectile point types from the site include Golondrina (Fig. 5,a), Lerma (Fig. 5,b), Baker (Fig. 5,c), Nolan (Fig. 5,d), Gower (Fig. 5,f), Pandale (Fig. 5,g), and Tortugas (Fig. 5,h). More detailed information on the probable age ranges and cultural affiliations of these and other types of projectile points found in the Lower Pecos Region is presented in books by Turner and Hester (1980) and Shafer (1986:58-83). There were two projectile points in the sample not readily attributable to any defined type. The first is a Bandy-like point (Fig. 5,e; Turner and Hester 1985:69); and the second is almost certainly an arrow point, possibly a Perdiz variant (Fig. 5 , i). The sample also contained several projectile point preforms or bifacial blanks (Fig. 5, j, k, 1). Based on their size range, these were probably dart point preforms. One Clear Fork unifacial tool (Turner and Hester 1980:208) was found during the excavation of a backhoe test trench at the site. Its presence, along with the presence of the Golondrina and the several varieties of other Early Archaic projectile points, may indicate that the site was occupied more heavily during its earlier cultural periods than during later times. 


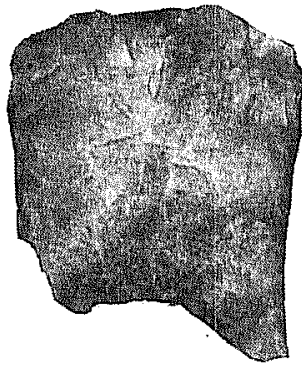

a

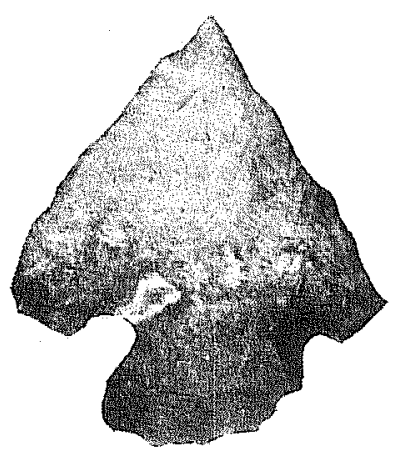

e

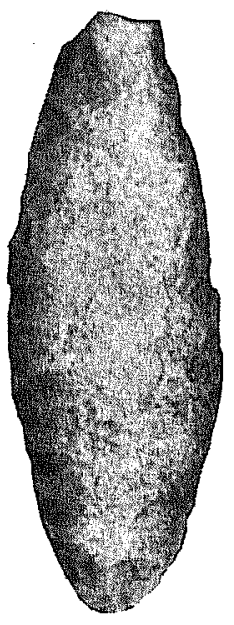

b

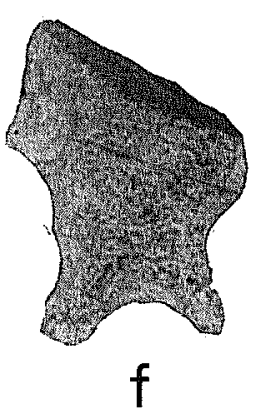

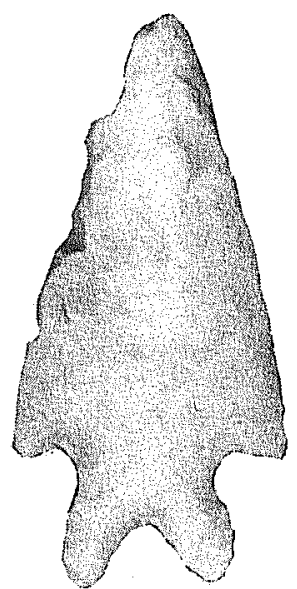

C

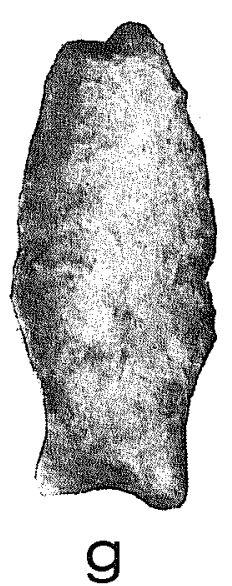

$\mathrm{g}$

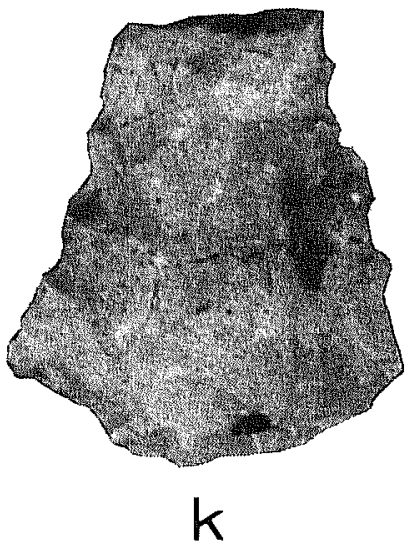

$5 \mathrm{~cm}$

Figure 5. Selected Lithic Artifacts from 41 VV 1251. a, Golondrina; b, Lerma; c, Baker; d, Nolan; e,Bandy-like; f, Gower; g, Pandale; h, Tortugas; i, unidentified arrow point; j-1, preforms. 


\section{SUMMARY AND CONCLUSIONS}

Although site 41 VV 1251 had been badly disturbed in modern times, the lithic artifacts systematically collected there lend additional credence to cultural and technological sequences established during prior investigations in the region. When arranged in typological/chronological order, the diagnostics from site 41 VV 1251 compare very favorably with both Johnson's (1964) and Shafer's (1986:130) projectile point sequences. Also, the relatively greater weight of Late Paleo-Indian and Early Archaic diagnostics in the collected sample might indicate a predominence of occupation at the site during those periods. However, due to the relatively small sample size and uncertain state of physical preservation at the site, caution must be used in making any definitive conclusions about the range and weight of prehistoric occupations there based on lithic analysis alone.

\section{REFERENCES CITED}

Black, S. L. and A. J. McGraw

1985 The Panther Springs Creek Site: Cultural Change and Continuity Within the Upper Salado Creek Watershed, South-Central Texas. Center for Archaeological Research, The University of Texas at San Antonio, Archaeological Survey Report 100.

Crabtree, D. E.

1972 An Introduction to Flintworking. Occasional Papers of the Idaho State University Museum 28. Pocatello, Idaho.

Dibble, D. S. and D. Lorrain

1968 Bonfire Shelter: A Stratified Bison Kill Site, Val Verde County, Texas. Texas Memorial Museum, The University of Texas at Austin, Miscellaneous Papers 1.

Hester, T. R.

1980 Digging Into South Texas Prehistory. Corona Publishing Company, San Antonio, Texas.
Johnson, L., Jr.

1964 The Devil's Mouth Site: A Stratified Campsite at Amistad Reservoir, Val Verde County, Texas. Department of Anthropology, The University of Texas at Austin, Archeology Series 6.

Jones, C. J., P. Foster, and J. W. Kunert

1979 Analysis of debitage material recovered from 1979 summer field school excavation at $41 \mathrm{BX} 271$ (Granberg II). Unpublished manuscript on file at the Center for Archaeological Research, The University of Texas at San Antonio.

Kelly, T. C.

19751975 flake analysis from 41 BX 271. Unpublished research paper on file at the Center for Archaeological Research, The University of Texas at San Antonio.

Mallouf, R. J.

1976 Archeological Investigations at Proposed Big Pine Lake, 1974-1975, Lamar and Red River Counties, Texas. Texas Historical Commission, Archeological Survey Report 18 , Austin.

Shafer, H. J.

1969 Archeological Investigations in the Robert Lee Reservoir Basin, West Central Texas. The University of Texas at Austin, Papers of the Texas Archeological Salvage Project 17.

1986 Ancient Texans: Rock Art and Lifeways Along the Lower Pecos. Published for the Witte Museum of the San Antonio Museum Association. Texas Monthly Press, Austin.

Turner, S. E. and T. R. Hester

1985 A Field Guide to Stone Artifacts of Texas Indians. Texas Monthly Press, Austin.

Word, J. H. and C. L. Douglas

1970 Excavations at Baker Cave, Val Verde County, Texas. Texas Memorial Museum, Bulletin 16. 


\title{
APPENDIX II: GEOMORPHOLOGY AND SOILS CHARACTERISTICS AT SITE 41 VV 1251
}

\author{
by James T. Abbott
}

\section{INTRODUCTION}

On February 3, 4, and 5, 1990, an initial geomorphic investigation was conducted within the boundary of a 105 -acre tract that is the site of a proposed expansion of an existing landfill operated by and for the city of Del Rio in Val Verde County, Texas. This area includes one known site (41 VV 1251), identified by pedestrian survey in September 1989 (Burkett 1990) The geomorphic investigation was conducted in tandem with Phase II archacological investigations of the site, and was designed to compliment archacological data recovery and interpretation by elucidating the character of the site matrix and local site context. More specifically, the purposes of the present investigation were as follows: (1) to assess the character of local depositional environments within and surrounding the tract, including 41 VV 1251; (2) to assess the nature, integrity, and temporal characteristics of deposits and associated soils in the locality; and (3) to prospect for buried long-term temporal surfaces (palaeosols) and/or occupation surfaces within the impact area, and in particular within the boundaries of 41 VV 1251. This report describes the methodology and results of this geomorphic investigation.

\section{METHODS}

Assessment of the geomorphic characteristics of the Del Rio Landfill locality was accomplished by integrating information obtained from existing sources, data derived from a survey of the character of sediments exposed at the surface and in natural cuts, and data obtained from a limited number of subsurface probes conducted with a backhoe. Prior to entering the field, relevant geologic and pedologic sources were assembled and examined, and existing soils and geologic maps were obtained for in-field use. The initial surface examination entailed a walk-over survey of the site and local environs, during which a sketch map of the general distribution of different types of exposed sediment was constructed on a base map derived from the Del Rio SE USGS 7.5' quadrangle. The second phase of field examination consisted of the excavation of several transects of backhoe trenches across portions of the study area in order to better examine the character and lateral variability of local sediments and soils and to obtain samples of selected horizons for laboratory analysis. Finally, basic textural and chemical analyses were conducted in the laboratory on samples collected from the backhoe trenches in order to quantify the major attributes of the soil profiles examined in the subsurface tests.

The sediment columns exposed by the trenches were described in the field using both graphic depictions and verbal descriptions of the exposures. The neutral term "zone" was adopted to allow both stratigraphic and pedogenic variation in sediment columns to be described under the same nomenclature. For each zone, the depth, thickness, texture, structure, consistence, reactivity with dilute $\mathrm{HCl}$ color, and the nature of the contact with the next lower unit were noted. All depths were recorded relative to the present ground surface. Texture was estimated according to the guidelines presented by Birkeland (1984). Structure, consistence, and boundary determinations follow Olson (1976) and the Soil Survey Staff (1951). Dilute $\mathrm{HCl}$ was used to determine reactivity, and thus suggest relative carbonate content. Color was recorded using a Munsell soil color chart (Munsell Color 1975). Due to a general lack of soil moisture, dry color was typically recorded, although moist color was recorded in a few cases. Horizon designations follow the system outlined by the Soil Survey Staff (1988), with the addition of the K horizon as described by Birkeland (1984). Bulk soil/sediment samples were collected from selected trenches for textural and limited chemical analysis. In most cases, one bulk sample was collected from each zone in a sampled trench, although in a few trenches samples were only collected from selected zones to limit data redundancy.

In addition to geomorphic and pedogenic attributes, each trench was carefully monitored for preserved archaeological materials during excavation. This was accomplished by: (1) slowly shaking the sediment out of the backhoe bucket so that exhumed artifacts could be recovered, and (2) periodically examining the trench walls for artifacts, features, and/or preserved temporal surfaces. With the exception of a few anomalously large, possibly burned clasts observed in the slope wash deposits, no artifacts were detected during excavation of any of the trenches.

Three analytical procedures were conducted in the laboratory on the sediment samples to quantify 
basic horizon characteristics and allow comparison of the degree of soil development between profiles exposed in the different trenches. A total of 18 samples was analyzed for organic matter, texture, and carbonate content. Results of the analyses are presented in Table 5.

Soil texture was determined by sieving and hydrometer analysis. Samples were prepared in two different ways depending on gravel content. Gravelly and loosely aggregated samples were weighed and passed through a $2-\mathrm{mm}$ sieve to recover the gravel fraction, and the fine fraction was then ground and split to obtain a subsample of approximately 50-60 g. Nongravelly, aggregated samples were subsampled by removing and grinding individual aggregates to obtain a subsample of approximately $50-60 \mathrm{~g}$. The samples were then soaked for 36 hours in a $5 \%$ sodium pyrophosphate solution to disaggregate the clays and submitted to hydrometer analysis. Hydrometer readings were taken at 1, 3.5, 45, and 300 minutes. The samples were then wet-sieved through a $64-\mu \mathrm{m}$ screen to recover the sand fraction, dried, and sieved at 1 phi intervals. These data were used to construct cumulative curves and calculate Folk's (1980) graphic textural statistics.

Organic matter was determined according to the method described by Graham (1948), which is a modification of the Walkley-Black method of organic carbon determination (Singer and Janitzky 1986) that uses colorimetry rather than titration for determination of concentration. One gram of air-dry 10 -mesh soil was placed in a $250 \mathrm{ml}$ Erlenmayer flask, and $10 \mathrm{ml}$ of $1 \mathrm{~N}$ potassium dichromates was added. Then $20 \mathrm{ml}$ of concentrated, reagent-grade sulfuric acid was added by means of a $100-\mathrm{ml}$ burette. The resulting mixture was agitated by hand for 10 seconds and allowed to stand for 10 minutes. One hundred $\mathrm{ml}$ of deionized $\mathrm{H}_{2} \mathrm{O}$ was then added, and the mixture was allowed to stand for two hours to let the solution clear. An aliquot of the supernatant liquid was then transferred into $1 / 2$-inch test tubes with a repipette and centrifuged one minute to remove all residual suspended matter. The transmittancy of the solution at $645 \mu \mathrm{m}$ incident light was then determined using a Bausch and Lomb Spectronic 20 spectrophotometer. Concentration was read off the curve provided by Graham (1948).

Carbonate content was determined by measuring the volume of $\mathrm{CO} 2$ evolved through the digestion of the carbonate fraction using the Chittick apparatus (Singer and Janitzky 1986). Samples submitted to the analysis were fine ground and weighed out to $0.85 \mathrm{~g}$. Carbonate concentration was determined from a regression line constructed by simultaneously submitting samples of pure, ground calcite weighing $0.08,0.17 .0 .34,0.51$, and $0.68 \mathrm{~g}$ (equivalent to calcite concentrations of $10 \%$, $20 \%, 40 \%, 60 \%$, and $80 \%$ ).

\section{PHYSIOGRAPHIC AND GEOLOGIC SETTING}

The study area is located in Val Verde County, Texas, on the southern margin of the Edwards Plateau near the boundary of the upper Rio Grande Plain. The general physiography of the southern Edwards Plateau is developed primarily on Cretaceous-age limestones and marls and may be described as moderately rolling to dissected (Golden, Gabriel, and Stevens 1982). The climate of the region is semiarid, and characterized by mild, dry winters and hot summers (Natural Fibers Information Center Staff 1987). The study area is located on the boundary between the Tamaulipan and Balconian biotic provinces (Blair 1950), resulting in a transitional floral/faunal assemblage. Vegetation in the region consists primarily of thorny scrub, succulents, compositae, and scattered grasses, with moderate to extensive patches of bare ground.

The study area is situated in a broad, shallow valley incised some 8-12 $\mathrm{m}$ into an undulating upland surface that overlooks the city of Del Rio to the northwest and the Rio Grande valley to the south and southwest. A prominent north-south trending scarp up to $30 \mathrm{~m}$ in height separates the uplands from the Calaveras Creek/San Felipe Creek valley to the west. The upland valley intersects this deeper valley at approximately right angles, and the site of this intersection is the location of the extant landfill. The study area is an extension of the landfill to the south and southeast of the current site.

The upland valley is oriented roughly northwest-southeast, and is manifest in the southeastern portion of the study area as a relatively wide, flat-bottomed swale with very gently sloping sides, and as a dissected, heavily modified erosional valley with relatively steep sides adjacent to the northeastern portion. The floor of the valley dips gently to the east-southeast in the eastern margin of the study area, suggesting that the valley contained a once active stream that drained eastward into the valley of Zorro Creek, and from there south to the Rio Grande. In contrast to the nearly level alluvial surface in the eastern half of the study area, the northwestern portion is dissected and markedly erosional, due primarily to the headward trenching of an arroyo that drains northwest into Calaveras Creek. This arroyo represents a drainage oriented 
TABLE 5. SUMMARY OF TEXTURAL AND CHEMICAL DATA

\begin{tabular}{|c|c|c|c|c|c|c|c|c|}
\hline Sample & Gravel \% & Sand $\%$ & Silt \% & Clay \% & Mean (phi) & S. D. (phi) & $\begin{array}{l}\text { Organic } \\
\text { Matter \% }\end{array}$ & $\mathrm{CaCO} 3 \%$ \\
\hline \multicolumn{9}{|l|}{ BHT 1} \\
\hline Zone 1 & 0.3 & 10.3 & 42.6 & 46.6 & 7.1 & 2.8 & 1.5 & 46 \\
\hline Zone 2 & 0.6 & 6.7 & 42.0 & 50.5 & 73 & 28 & 1.6 & 56 \\
\hline Zone 3 & 0.9 & 6.1 & 41.8 & 51.1 & 73 & 2.8 & 0.8 & 64 \\
\hline Zone 4 & 27.0 & 5.4 & 29.2 & 38.4 & 4.6 & 5.7 & 0.2 & 62 \\
\hline Zone 5 & Not sampled & & & & & & & \\
\hline \multicolumn{9}{|l|}{ BHT 2} \\
\hline Zone 1 & 0.05 & 10.6 & $\$ 9.4$ & 30.0 & 6.0 & 2.5 & 1.5 & 35 \\
\hline Zone 2 & 03 & 5.1 & 375 & 57.1 & 7.7 & 25 & 1.4 & 42 \\
\hline Zone 3 & 1.2 & 7.4 & 47.4 & 44.0 & 6.8 & 2.8 & 0.4 & 60 \\
\hline Zone 4 & 0.6 & 5.7 & 41.2 & 524 & 7.4 & 28 & $<0.1$ & 60 \\
\hline BHT 3 & Not sampled & & & & & & & \\
\hline \multicolumn{9}{|l|}{ BHT 4} \\
\hline Zone 1 & 25 & 13.1 & 47.3 & 37.1 & 6.5 & 2.7 & 1.1 & 41 \\
\hline Zone 2 & 1.3 & 9.9 & 37.9 & 50.9 & $7 A$ & 2.9 & 0.2 & 53 \\
\hline Zone 3 & 65.6 & 5.5 & 10.6 & 183 & 1.6 & 4.0 & 0.6 & 63 \\
\hline \multicolumn{9}{|l|}{ BHT 5} \\
\hline Zone 1 & 14.1 & 6.0 & 37.8 & 41.9 & 6.1 & 3.8 & 2.8 & 28 \\
\hline Zone 2 & 0.07 & 5.6 & 40.2 & 54.2 & 7.6 & 2.8 & 1.9 & 33 \\
\hline Zone 3 & 0 & 4.6 & 37.6 & 57.7 & 7.7 & 2.9 & 0.6 & 39 \\
\hline Zone 4 & 0.2 & 4.6 & 33.8 & 61.4 & 7.8 & 2.8 & 0.7 & 41 \\
\hline Zone 5 & 52.8 & 3.1 & 15.8 & 28.2 & 19 & 4.6 & 0.2 & 49 \\
\hline Zone 6 & 3.9 & 6.1 & 44.0 & 45.8 & 7.2 & 2.5 & 0 & 57 \\
\hline \multicolumn{9}{|l|}{ BHT 6} \\
\hline Zone 1 & Not sampled & & & & & & & \\
\hline Zone 2 & Not sampled & & & & & & & \\
\hline Zone 3 & 1.9 & 4.3 & 29.7 & 64.0 & 7.9 & 29 & 1.5 & 41 \\
\hline Zone 4 & Not sampled & & & & & & & \\
\hline
\end{tabular}


in what was originally an up-valley direction, and may be the result of a natural response to disturbance of the original landscape by landfill activities and/or the retreat of the upland scarp overlooking Calaveras Creek. The northwestern half of the study area is situated on the dissected slope of the southern valley wall, and is broken by several north-south oriented, headward-trenching tributary arroyos separated by fingerlike extensions of the sloping upland surface.

Bedrock underlying the site consists of upper Cretaceous Del Rio clays overlain by upper Cretaceous Buda limestones and Pliocene and Pleistocene alluvial deposits with caliche, possibly associated with the Uvalde Gravel. The Del Rio clay, which forms the basal deposit exposed along the upland scarp, consists of blocky, fossiliferous, calcareous to gypsiferous clay that weathers light gray to yellowish gray. This unit is overlain by massive, poorly bedded to nodular, fine-grained, light gray to pale orange Buda limestones.

The upland is capped with a predominantly fine-grained calcrete at least $1.5-2 \mathrm{~m}$ in thickness. This unit is mapped as Uvalde Gravel by Barnes (1977); however, no deposits characteristic of the Uvalde Gravel were observed in the field. The Uvalde Gravel is a widely recognized, yet poorly understood, formation that consists of mixed lithology gravels that are frequently calcitecemented and occur intermittently on topographic high points over a wide area east of the Balcones Fault Zone. Uvalde Gravel is generally interpreted as the remains of alluvium deposited during the Pliocene or early Pleistocene by alluvial systems unrelated to the modern drainage network (Sellards, Adkins, and Plummer 1932:777-779; Barnes et al. 1972:46), and is dominated by chert and other relatively resistant siliceous clasts, while chemically susceptible limestone clasts are almost entirely absent (Sellards, Adkins, and Plummer 1932). In contrast, the calcrete observed capping the upland surface surrounding the study area is developed in fine-grained deposits and almost entirely lacking in gravels. This, combined with the fact that no appreciable siliceous material was observed in the gravelly deposits preserved in the upland valley, suggests that the calcrete cap should not be equated with the Uvalde Gravel; although it is possible that the deposit represents a temporally related fine-grained depositional facies, it is equally possible that the calcrete represents a more recent (e.g., middle to late Pleistocene) alluvial deposit.

Soil series mapped in the vicinity of the study area by the Soil Conservation Service include Olmos, Zapata, and Vinegaroon soils developed on the uplands surrounding the drainage; Acuna silty clay on the valley slopes; and Tobosa clay in the valley axis. Olmos soils are calcic mollisols, while Zapata and Vinegaroon soils are well-developed aridisols. All three are characterized by the presence of a petrocalcic horizon. Acuna soils are classified as calcic mollisols, and Tobosa soils are classified as vertisols (Golden, Gabriel, and Stevens 1982).

\section{LOCAL PHYSIOGRAPHY AND DESCRIPTION OF SURFICIAL SEDIMENTS}

The confines and immediate surroundings of the investigated tract vary systematically in response to slope; the character of surficial sediment directly reflects a dominance of sheet wash erosional processes and the ease with which slope wash sediment can be flushed into the alluvial system and removed. In general, the steeper side slopes at the northwestern end of the study area are almost entirely erosive, with calcrete or bedrock exposed at the surface, while the side slopes in the remainder of the study area are mantled by a thin blanket of mixed alluvial/colluvial material derived from slope wash and (to a lesser extent) creep processes. Even though these deposits are actually the result of a complex suite of interrelated alluvial and colluvial processes, for the sake of brevity and the want of a better term they will be collectively referred to as "slope wash" deposits in the following sections.

In the central valley axis, the southeastern portion of the study area is infilled with several meters of alluvium, forming a level, broad flat several hundred meters across. While it was probably once a level flat nearly identical to the southeastern end, the character of the northwestern margin of the study area in the central valley has been strongly affected by headward trenching of the westward-flowing drainage. Here, more effective erosion has removed the overlying fines, resulting in exposure and partial dissection of basal valley-fill gravels. The general distribution of surface sediment types in the study area is illustrated in Figure 6.

Site 41 VV 1251, the focus of archaeological testing activities conducted in tandem with the geomorphic investigation, is located on the valley side slope and encompasses both dominantly erosional and slope wash-mantled surfaces. The majority of the site is mantled with intermittently active slope wash sediment and contains a number of loci where light to moderate lithic scatters and small burned rock features are present at the surface and in the shallow subsurface. Localized sheet wash erosion and deposition are the prevalent 


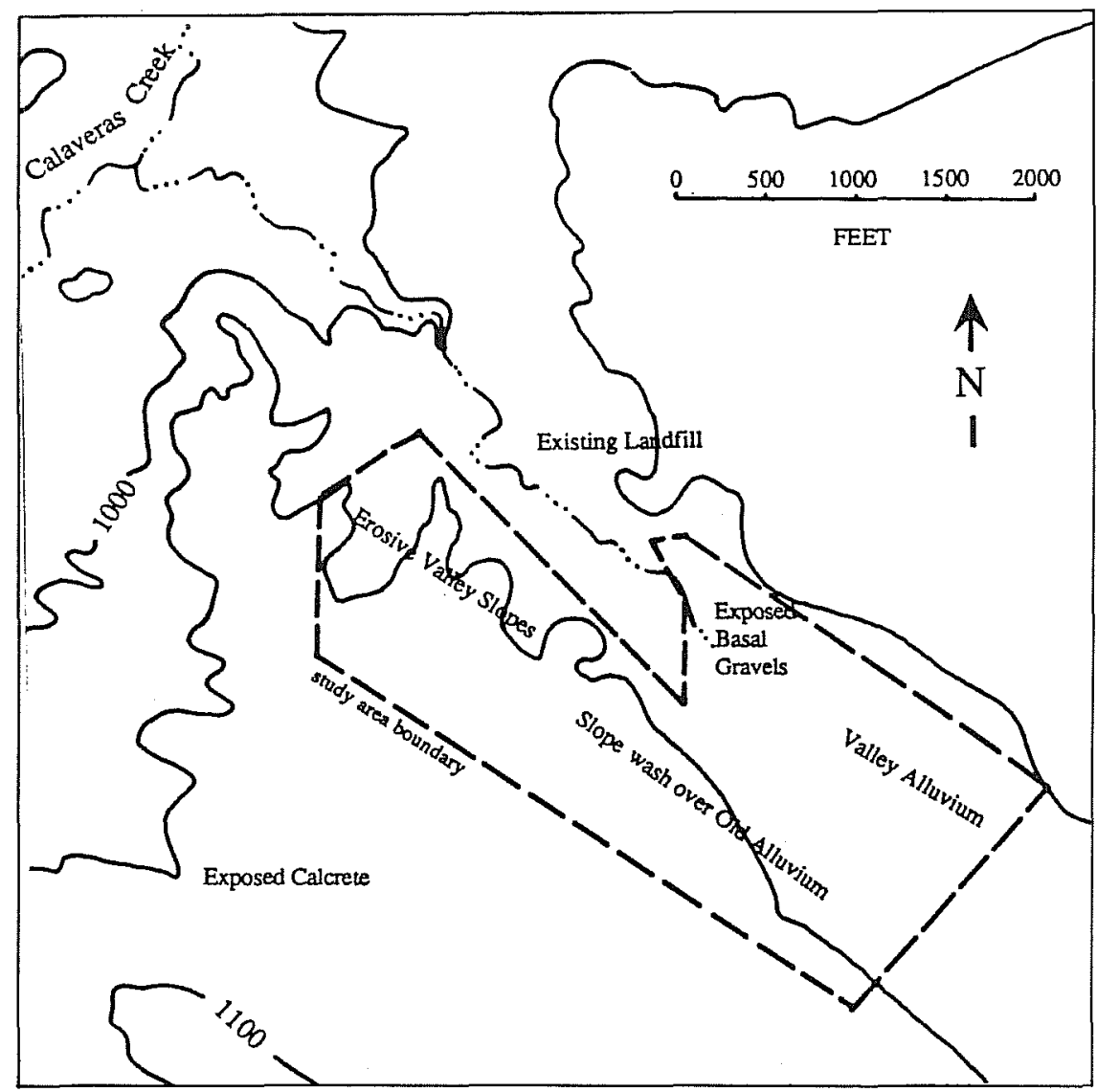

Figure 6. Generalized Distribution of Sediment Types in the Study Area. Elevations and scale are presented in feet to allow comparison with existing topographic maps.

north-south oriented arroyos and the edge of the upland alluvial body along the northeastern margin of 41 VV 1251. Although some of the water in these ponds may issue from the exposed basal gravel deposits, no travertine, subhorizontally banded carbonate, or other types of evidence indicating appreciable groundwater flow was detected, and it is probable that these ponds are recent features resulting primarily from blocking of the overland drainage patterns by human activity in the adjacent dump site.

As a result of erosion of overlying soils at an unknown time in the past, the calcrete cap on the higher parts of the upland landscape to the south and southwest of the study tract is exposed at the surface and littered with archaeological detritus, including limited PaleoIndian materials. It is unclear whether the exposed caliche represents the actual occupation surface or an erosional lag surface on which the materials were concentrated; however, in either case, the potential for

geomorphic process currently affecting most areas of the site. One very common type of physical feature on the site is a broad erosional "rill" approximately $20-200 \mathrm{~cm}$ in width and 1 to $3 \mathrm{~cm}$ deep that represents the localized effects of sheet wash erosion. These features are the result of headward-cutting scour of the surface, often evidence a near-vertical microtopographic scarp $1-3 \mathrm{~cm}$ high at the upslope end, and are common where overland flow is concentrated by shrubs or other clumps of vegetation. Many of the artifacts and archaeological features present on the surface are exposed as lag clasts in these erosional rills. A second important characteristic of the soils on the side slope was a tendency to develop deep cracks due to clay contractions.

At present, small ephemeral ponds and associated arroyos are incised into the valley alluvium at the junction of several of the small, buried deposits in the caliche cap is almost nonexistent.

In addition to incremental downwasting due to sheet erosion, the caliche cap on the uplands is being subjected to lateral erosion at several locations on the margins of the rolling upland surface. This backwasting is manifest as several localized scarps up to $50 \mathrm{~cm}$ in height around the steeper margins of the upland surface, and as at least one isolated erosional remnant on one of the fingerlike upland prominences. It is likely that much of the highly calcareous slope wash sediment mantling the lower valley slope is derived from erosion of this upland caliche cap. 
DESCRIPTION OF SUBSURFACE INVESTIGATIONS

In order to better define the character of subsurface deposits in the study area, a series of seven backhoe trenches was excavated within the confines of the study area (Fig. 7). These probes were limited to the portion of the expansion tract where an appreciable volume of alluvium is preserved in the valley. No attempt was made to trench the subsurface in the dominantly erosive western half of the study area; however, brief examination of natural exposures and several of the archaeological test units hand-excavated in the northwestern end of $41 \mathrm{VV} 1251$ suggested that even when present, the surface mantle is relatively thin. The following paragraphs summarize the general character of subsurface sediments revealed by trenching and provide interpretation of the depositional environments represented; detailed descriptions of each trench are presented in Table 6.
Backhoe trenches (BHT) 1-3 were excavated along a transect that extended from the vicinity of the stock dam in the southeastern portion of site 41 VV 1251 south to the study area boundary. BHT 1 was situated near a prehistoric activity locus consisting of scattered debitage and several shallowly buried burned rock features. This material was exposed at the surface by a combination of artificial disturbance and subsequent natural adjustment of the local landscape associated with construction of a small stock dam. BHT 2 and BHT 3 were located at intervals of approximately $100 \mathrm{~m}$ on a line extending south of BHT 1, and represent a transect extending across the gently sloping alluvial surface toward the upland valley wall.

The surficial zone in BHT 1 was $32 \mathrm{~cm}$ thick and consisted of highly calcareous, brown, friable, slightly gravelly silty clay loam. The frequency of gravels increased towards the base of the zone, which was separated from the underlying zone by a clear, possibly erosional boundary. Chemical analyses conducted on a sample collected from the

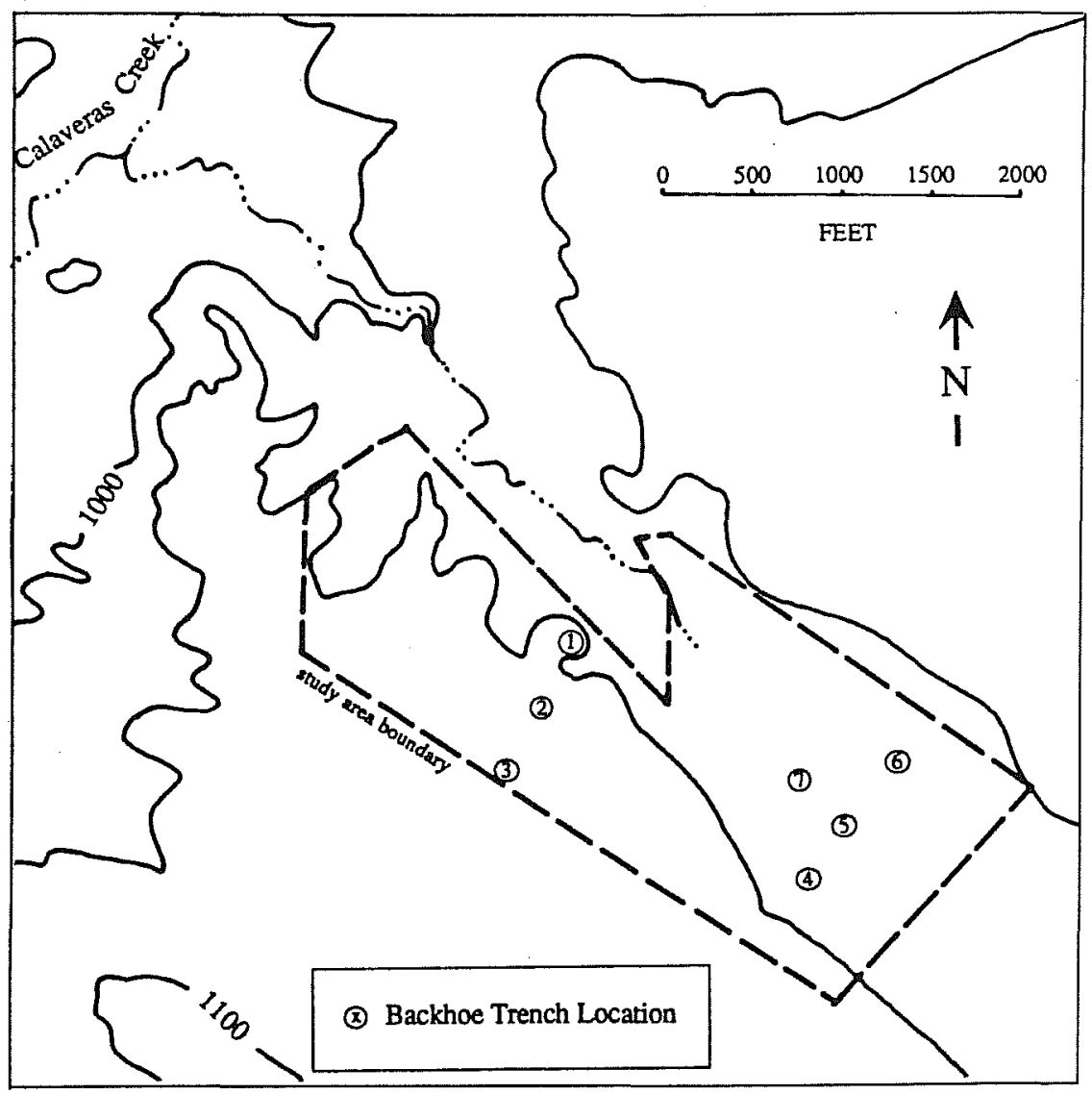

Figure 7. Generalized Location of Backhoe Trenches in the Study Area. zone indicated an organic matter content of $1.5 \%$ and a carbonate content of $46 \%$. All archaeological materials observed at the site were associated with this surficial zone, which is interpreted as slope wash or mixed alluvium and slope wash sediment deposited over an older, truncated alluvial soil. This buried soil is represented by Zones $2-4$, extending from 32 to $120 \mathrm{~cm}$ in BHT 1 . These zones consist of very pale brown, very strongly calcareous sediment that grades from predominantly silty clay loam to gravelly clay loam with depth. Organic matter content decreases sharply with depth, ranging from $1.6 \%$ in Zone 2 to $0.2 \%$ in Zone 4, while carbonate content 
TABLE 6. TRENCH DESCRIPTIONS

\begin{tabular}{|c|c|c|}
\hline Sample & Location & Description \\
\hline \multicolumn{3}{|l|}{ BHT 1} \\
\hline Zone 1 & $0-32 \mathrm{~cm}$ & $\begin{array}{l}\text { Slightly gravelly silty loam to silty clay loam; massive to weak coarse granular } \\
\text { structure; friable; brown (10YR 5/3); very strongly calcareous; clear, possibly } \\
\text { erosional boundary; A1 horizon; probable slope wash deposit over older truncated } \\
\text { soil. }\end{array}$ \\
\hline Zone 2 & $32-60 \mathrm{~cm}$ & $\begin{array}{l}\text { Silty loam to silty clay loam; massive to very weak coarse blocky structure; soft; very } \\
\text { pale bnown (10YR 7/3); very strongly calcareous; gradual boundary; abundant } \\
\text { secondary accumulation filamental and interstitial carbonate; 2B1k horizon. }\end{array}$ \\
\hline Zone 3 & $60-102 \mathrm{~cm}$ & $\begin{array}{l}\text { Silty clay loam to gravelly silty clay loam; fine subangular blocky structure; soft to } \\
\text { slightly hard; very pale brown (10YR } 7 / 3) \text {; very strongly calcareous; gradual } \\
\text { boundary; contains dispersed limestone granules; abundant secondary accumulation } \\
\text { filamental and interstitial carbonate and soft carbonate masses to approximately } 1 \\
\text { cm dinmeter; } 2 \mathrm{~B} 2 \mathrm{k} \text { horizon. }\end{array}$ \\
\hline Zone 4 & $102-120 \mathrm{~cm}$ & $\begin{array}{l}\text { Gravelly clay loam; fine angular blocky structure; hard; very pale brown (10YR } \\
7 / 3 \text { ); very strongly calcareous; gradual boundary; contains abundant limestone } \\
\text { granules and pebbles; } 2 \text { C1k horizon. }\end{array}$ \\
\hline Zone 5 & $120 \mathrm{~cm}$-base of trench $(140 \mathrm{~cm})$ & $\begin{array}{l}\text { Silty ciay gravels; massive; loose to friable; very pale brown (10YR } 7 / 3 \text { ); very } \\
\text { strongly calcareous; contains limestone gravels exclusively; clasts to } 15 \mathrm{~cm} \text { diameter, } \\
2 \mathrm{C} 2 \mathrm{k} \text { horizon. }\end{array}$ \\
\hline \multicolumn{3}{|l|}{ BHT 2} \\
\hline Zone 1 & $0.30 \mathrm{~cm}$ & $\begin{array}{l}\text { Slightly gravelly silty loam to silty clay loam, massive to weak coarse granular } \\
\text { structure; soft to slightly hard; dark grayish brown (10YR } 4 / 2 \text {, moist); very strongly } \\
\text { calcareous; gradual boundary; A1 horizon. }\end{array}$ \\
\hline Zone 2 & $30-70 \mathrm{~cm}$ & $\begin{array}{l}\text { Silty loam to silty clay loam; weak fine subangular blocky structure; soft to slightly } \\
\text { hard; light brownish gray (10YR6/2); very strongly calcareous; gradual to clear } \\
\text { boundary; abundant secondary accumulation filamental and interstitial carbonate; } \\
\text { soft carbonate masses to approximately } 0.5 \mathrm{~cm} \text { diameter below } 50 \mathrm{~cm} ; 2 \mathrm{~B} 1 \mathrm{k} \\
\text { horizon. }\end{array}$ \\
\hline Zone 3 & $70-130 \mathrm{~cm}$ & $\begin{array}{l}\text { Silty loam to clay loam; medium subangular blocky structure; soft to slightly hard; } \\
\text { very pale brown (10YR 7/3); very strongly calcareous; diffuse boundary; contains } \\
\text { dispersed limestone granules; abundant secondary accumulation filamental and } \\
\text { interstitial carbonate; soft carbonate masses to approximately } 1 \mathrm{~cm} \text { diameter, } 2 \mathrm{~B} 2 \mathrm{KK} \\
\text { horizon. }\end{array}$ \\
\hline Zone 4 & $130 \mathrm{~cm}$ base of trench $(150 \mathrm{~cm})$ & $\begin{array}{l}\text { Clay loam to clay; fine angular blocky structure; hard; very pale brown (10YR 7/3); } \\
\text { very strongly calcareous; abundant secondary accumulation interstitial carbonate } \\
\text { and soft carbonate masses to approximately } 1 \mathrm{~cm} \text { diameter; } 2 \mathrm{Ck} \text { horizon. }\end{array}$ \\
\hline BHT 3 & & \\
\hline Zone 1 & $0-30 \mathrm{~cm}$ & $\begin{array}{l}\text { Slightly gravelly silty loam; massive to weak coarse granular structure; friable; } \\
\text { brown (10YR 5/3, moist); very strongly calcareous; clear to gradual boundary, } \\
\text { contains few dispersed limestone gravels; A1 horizon. }\end{array}$ \\
\hline Zone 2 & $30.55 \mathrm{~cm}$ & $\begin{array}{l}\text { Slightly gravelly silty clay loam; massive to weak coarse subangular blocky structure; } \\
\text { soft ta slightly hard; brown (10YR } 5 / 3 \text { ); very strongly calcareous; clear boundary; } \\
\text { common secondary accumulation filamental and interstitial carbonate masses to } \\
\text { approximately } 0.5 \mathrm{~cm} \text { diameter below } 40 \mathrm{~cm} \text {; few dispersed limestone gravels; B1k } \\
\text { horizon. }\end{array}$ \\
\hline Zone 3 & $55-105 \mathrm{~cm}$ & $\begin{array}{l}\text { Silty loam; massive to weak subangular blocky structure; slightly hard; very pale } \\
\text { brown (10YR 7/3); very strongly calcareous; diffuse boundary; abundant secondary } \\
\text { accumulation filamental and interstitial carbonate and soft cartonate masses to } \\
\text { approkimately } 2 \mathrm{~cm} \text { diameter; 2B2k horizon. }\end{array}$ \\
\hline Zone 4 & $105 \mathrm{~cm}$-base of trench $(130 \mathrm{~cm})$ & $\begin{array}{l}\text { Clay loam to clay; fine to medium angular blocky structure; hard; very pale brown } \\
\text { (10YR } 7 / 3 \text { ); very strongly calcareous; abundant secondary accumulation interstitial } \\
\text { carbonate and soft carbonate masses to approximately } 2 \mathrm{~cm} \text { diameter, } 2 \mathrm{Ck} \text { horizon. }\end{array}$ \\
\hline
\end{tabular}


Table 6. (continued)

\begin{tabular}{|c|c|c|}
\hline Sample & Location & Description \\
\hline \multicolumn{3}{|l|}{ BHT 4} \\
\hline Zone 1 & $0-35 \mathrm{~cm}$ & $\begin{array}{l}\text { Silty clay loam; medium granular structure; frisble; brown ( } 10 \mathrm{YR} S / 3 \text {, moist); very } \\
\text { strongly calcareous; gradual to diffuse boundary; Al horizon. }\end{array}$ \\
\hline Zone 2 & $35-85 \mathrm{~cm}$ & $\begin{array}{l}\text { Slightly gravelly silty clay loam; weak medium subangular blocky structure; slightly } \\
\text { hard; bruwn (10YR 5/3) to very pale brown (10YR 7/3) with depth; very strongly } \\
\text { calcareous; clear to gradual boundary; common secondary accumulation filamental } \\
\text { and interstitial carbonate increasing with depth; few dispersed limestone gravels; } \\
\text { B1k horizon. }\end{array}$ \\
\hline Zone 3 & $85 \mathrm{~cm}$ base of trench $(95 \mathrm{~cm})$ & $\begin{array}{l}\text { Gravelly clay to gravel with depth; massive; loose; very pale brown (10YR 7/3); very } \\
\text { strongly calcareous; common secondary accumulation interstitial carbonate in } \\
\text { matrix; exclusively limestone gravels to } 15 \mathrm{~cm} \text { diameter; } 2821 \text { horizon. }\end{array}$ \\
\hline \multicolumn{3}{|l|}{ BHT 5} \\
\hline Zone 1 & $0.8 \mathrm{~cm}$ & $\begin{array}{l}\text { Gravelly silty clay loam; massive; soft; light brownish gray (10YR6/2); strongly } \\
\text { calcareous; clear boundary; Al borizon; probable recent slope wash deposit. }\end{array}$ \\
\hline Zone 2 & $8-22 \mathrm{~cm}$ & $\begin{array}{l}\text { Slightly gravelly clay; massive; sticky, very firm; very dark brown (10YR } 2 / 2) \text {; } \\
\text { strongly calcareous; clear boundary; few dispersed limestone gravels; 2A2 horizon. }\end{array}$ \\
\hline Zone 3 & $22.37 \mathrm{~cm}$ & $\begin{array}{l}\text { Slightly gravelty clay; medium subangular blocky structure; very firm; very dark } \\
\text { grayish brown (10YR } 3 / 2) \text {; strongly calcareous; gradual boundary; contains } \\
\text { dispersed limestone granules and pebbles; common sot carbonate masses to } \\
\text { approximately } 1 \mathrm{~cm} \text { diameter, } 2 \mathrm{~B} 1 \mathrm{k} \text { horizon. }\end{array}$ \\
\hline Zone 4 & $37-66 \mathrm{~cm}$ & $\begin{array}{l}\text { Gravelly clay; medium angular blocky structure; hard to very hard dark grayish } \\
\text { brown (10YR 4/2); very strongly calcareous; gradual boundary; contains abundant } \\
\text { limestone granules and pebbles; abundant soft carbonate masses to approximately } 1 \\
\mathrm{~cm} \text { diameter; } 2 \mathrm{~B} 2 \mathrm{k} \text { horizon. }\end{array}$ \\
\hline Zone 5 & $66-96 \mathrm{~cm}$ & $\begin{array}{l}\text { Gravelly clay; medium angular blocky structure; hard; pale brown (10YR 6/3); very } \\
\text { strongly calcareous; gradual boundary; contains abundant limestone gravels to } 10 \\
\text { cm diameter, abundant soft carbonate masses to approximately } 1 \mathrm{~cm} \text { diameter; } \\
\text { 2B3k horizon. }\end{array}$ \\
\hline Zone 6 & $96 \mathrm{~cm}$ base of trench $(120 \mathrm{~cm})$ & $\begin{array}{l}\text { Gravelly clay; medium angular blocky structure; hard to very hard; brownish yellow } \\
\text { (10YR } 6 / 6) \text {; very strongly calcareous; contains abundant limestone gravels to } 15 \mathrm{~cm} \\
\text { diameter; } 2 \mathrm{BC} \text { horizon. }\end{array}$ \\
\hline
\end{tabular}

\section{BHT 6}

Zone 1

$0-8 \mathrm{~cm}$

Zone 2

$8-35 \mathrm{~cm}$

Zone 3
Slightly gravelly silty clay loam to silty clay; massive; friable; grayish brown (10YR 5/2); very strongly calcareous; gradual boundary; Al horizon; probable recent slope wash deposit.

Clay; massive to medium subangular blocky structure with depth; sticky, very firm; very dark grayish brown (10YR 3/2); strongly calcareous; gradual boundary; few dispersed limestone gravels; A2 horizon.

Slightly gravelly clay; medium subangular blocky structure; very hard; very dark brown (10YR 3/1); strongly calcareous; clear to abrupt boundary, probably erosional; contains dispersed limestone granules and pebbles increasing in frequency towards base; $\mathrm{AB}$ horizon.

Silty gravel; massive; soft to slightly hand; light gray (10YR 7/2); very strongly calcareous; carbonate-cemented; limestone gravels to $30 \mathrm{~cm}$ diameter, $2 \mathrm{~K}$ horizon.

BHT 7

$\begin{array}{ll}\text { Zone } 1 & 0-8 \mathrm{~cm} \\ \text { Zone } 2 & 8-100 \mathrm{~cm}\end{array}$

Gravelly silty loam; massive; soft; dark yellowish brown (10YR 4/4); very strongly calcareous; clear boundary; Al horizon; probable recent slope wash deposit.

Clay; massive; sticky, very firm; very dark gray (10YR 3/1); strongly calcareous; clear boundary; tew dispersed limestone gravels; abundant sof carbonate masses to approximately $1 \mathrm{~cm}$ diameter below $50 \mathrm{~cm} ; 2 \mathrm{~B} 1 \mathrm{k}$ horizon.

Slightly gravelly silty clay; massive; soft to slightly hand; light gray (10YR $7 / 2$ ); very strongly calcareous; few fine limestone gravels; heavily indurated by carbonate; up to $30 \%$ carbonate masses by volume; $2 \mathrm{~K}$ horizon. 
increases from $56 \%$ to $62 \%$ with depth. The morphology of secondary carbonate grades from filamental and matrix precipitates into relatively large, soft nodular masses with depth. The basal zone consists of clast-supported limestone gravels infilled with a carbonate-rich, silty clay matrix, and represents channel sediments deposited in the valley axis by the former stream. A graphic summary of the character of BHT 1 is illustrated in Figure 8.

BHT 2 and BHT 3 exhibited profiles similar to that exposed in BHT 1 , and probably represent a similar depositional sequence. However, two major differences are apparent between the latter profiles and the profile described previously. First, the upper slope wash sediment contains slightly more limestone gravel, which probably reflects the shorter distance from the sediment source on the adjacent valley wall. Second, the basal deposits consist of clay rather than gravel, and probably represent distal floodplain deposits associated with the channel deposits exposed in BHT 1.

BHT 4-BHT 6 were excavated along a transect across the central valley axis at the southeastern end of the study area, and included soil profiles characteristic of the lower side slopes and the central valley axis. Of these, BHT 4 was located on the lower side slope and exhibited a profile similar to BHT 1, BHT 6 exhibited markedly different characteristics representative of the sediment in the central valley, and BHT 5 represented a transition between the slope and valley axis. In addition, BHT 7 was excavated slightly northwest of the transect in a topographic position roughly analogous to BHT 5, and exhibited another example of a profile located in the transition from valley slope deposits to valley axis deposits.

The surfical zone in BHT 5 was $8 \mathrm{~cm}$ thick and consisted of light brownish gray, highly organic, calcareous silty clay loam representing moderately leached slope wash deposits. This zone was underlain by a soil developed in deposits composed primarily of alluvium with some colluvial/slope wash input. Zone 2 extended to a depth of $22 \mathrm{~cm}$ and consisted of a slightly gravelly, massive, very dark brown, organic calcareous clay. It is likely that the contact represents an unconformity, and that this zone is related to the sediment exposed in Zones 2 and 3 of BHT 6 (described later). The underlying zones (3-6) extended to a depth of 120 $\mathrm{cm}$ and consisted of gravelly clay that graded from dark grayish brown to brownish yellow with depth due to the increasing concentration of secondary carbonate in the clay matrix. Chemical analysis of samples from the trench revealed a sharp decrease in organic matter concentration from $2.8 \%$ in Zone 1 to $0 \%$ in Zone 6 , and a concomitant increase in carbonate concentration from $28 \%$ to $57 \%$.

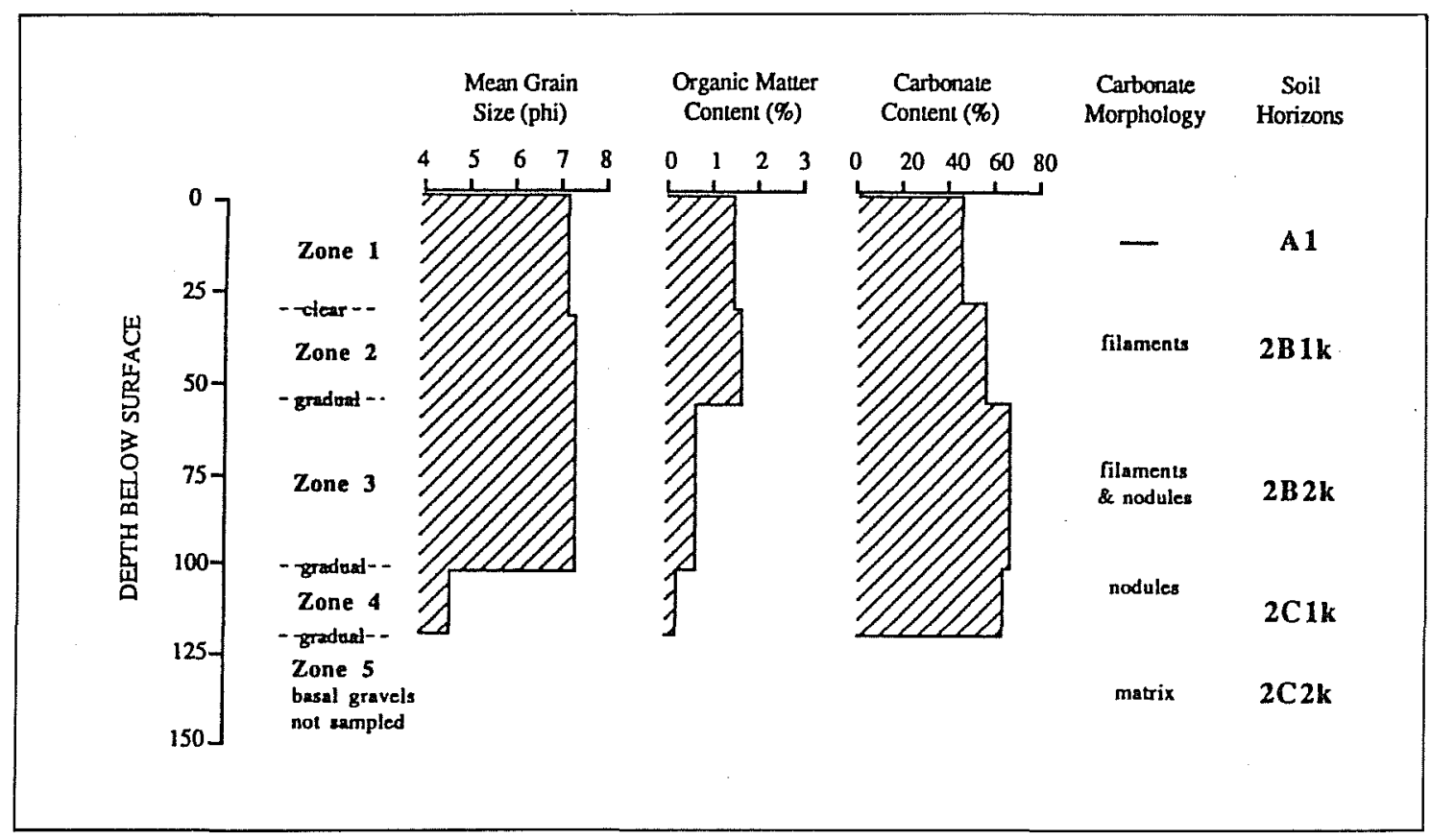

Figure 8. Textural and Chemical Characteristics of the Profile Exposed in BHT 1. 
Secondary carbonate morphology evidenced a transition from filaments and soft nodules in Zone 3 , through increasingly common nodules in Zones 4 and 5 , to a predominence of matrix carbonate in Zone 6. A graphic summary of the character of BHT 5 is illustrated in Figure 9.

BHT 6 is representative of sediments at the lowest elevations in the valley axis. The surficial zone was $8 \mathrm{~cm}$ thick and consisted of slightly gravelly grayish brown, organic, highly calcareous silty clay loam representing slope wash deposits. Zones 2 and 3, to a depth of $95 \mathrm{~cm}$, consisted of very dark gray, moderately calcareous, highly organic clay, and were separated from the underlying unit by an abrupt erosional contact. These zones are tentatively interpreted as a clay plug that infilled the former channel in the valley axis. The basal zone extended to the base of the trench at $110 \mathrm{~cm}$ and consisted of a high amount of caliche, clast-supported limestone gravel representing older channel deposits.

TEMPORAL CHARACTERISTICS, INTEGRITY, AND ARCHAEOLOGICAL POTENTIAL OF SEDIMENTS IN THE STUDY AREA

No radiometric data were collected during the field investigation, and as a result no quantitative data regarding the ages of sediments preserved in the study area are available. However, tentative temporal interpretations are possible based on integration of soil development and archaeological data. The following paragraphs develop these interpretations.
The oldest diagnostic artifacts recovered on 41 VV 1251 date to the Paleo-Indian. However, the earliest occupation evidence belongs to the Early Archaic period, and is associated with relatively intact hearths preserved in the upper slope wash horizon. Therefore, it appears that this body of sediment began to accumulate by the middle Holocene at the latest and continued to accumulate, at least episodically, to the present. However, while the general age of the upper unit appears amenable to site preservation, its integrity is questionable for several reasons. First, a strong degree of recent geomorphic activity is apparent, and a considerable number of lithics are exposed at the surface as lag clasts. If this process has been continuing for an appreciable period of time, or has occurred episodically in the past, it is likely that much of the original context has been destroyed as the artifacts have been alternately exhumed and reburied. The effects of this type of activity would be difficult to discern through examination of the sediment column due to (1) the fine texture and complete lack of sedimentary structures in the silty clay sediment typical of the slope wash mantle, and (2) the fact that the larger artifacts and burned rock features would be relatively unaffected by the moderate energy resulting from overland flow, and would therefore appear relatively intact even if the containing matrix had been partially eroded and redeposited several times. However, because lithics that had been exhumed and then reburied should be concentrated on former lag surfaces and/or buried erosional rills within the matrix, the integrity of the deposits might be determined through careful recording of the three-dimensional context of and temporal relationships between

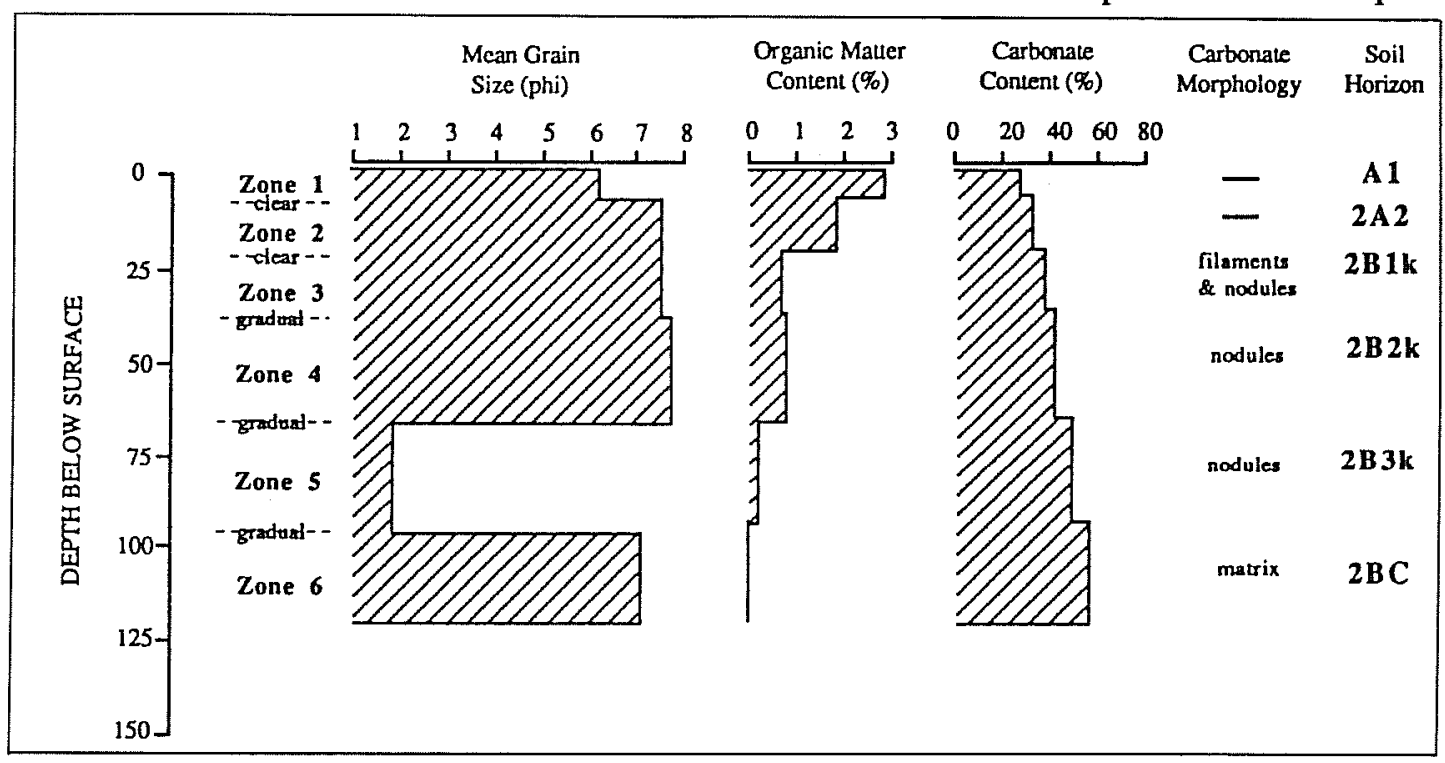

Figure 9. Textural and Chemical Characteristics of the Profile Exposed in BHT 5. 
time-diagnostic or lithologically distinct tools and debitage.

A second characteristic that makes the overall stratigraphic integrity of the upper slope wash deposits questionable is cracking of the surface horizon due to clay contraction. This tendency, although not ubiquitous, was observed in several localities on the slope wash-mantled surface, and probably becomes more widespread during the summer season. One of the principal consequences of pronounced clay expansion and contraction is mixing of the sediment matrix-and artifacts contained therein-as material falls down the cracks or is pushed toward the surface by expansion (Wood and Johnson 1978).

The underlying alluvial deposits on the valley side slopes exhibit strong horizonation, particularly in regards to the accumulation of secondary carbonate, suggesting that vertisolic mixing of the entire profile does not occur. Although the age of the deposits is not certain, the strong soil development suggests some antiquity, particularly given the very slow rate of infiltrations suggested by the clayey texture of the deposits. This, combined with the truncation of the former A horizon and the subsequent initial deposition of the surficial slope wash by the middle Holocene, strongly suggests that the underlying soil is of late Pleistocene age.

The alluvium exposed in BHT 6 and in Zone 2 of BHT 5 is generally darker, more organic-rich, and less calcareous than the sediment in the other trenches. Although BHT 6 was not sampled extensively, one sample collected from the lower portion of Zone 3 proved significantly less calcareous and more highly organic than samples taken from similar depths in the other trenches (see Table 5). Also, visible secondary carbonate in BHT 6 is limited to a few fine filaments, in stark contrast to the strong filamental and nodular morphology evident in the other trenches. Several explanations are possible for the differences in secondary carbonate and organic matter concentration apparent between BHT 6 and the remainder of the trenches. These differences may be the result of (1) more effective leaching and organic translocation due to intermittent ponding in the lowest areas in the valley axis; (2) more effective vertisolic mixing of the sediment in the valley axis; (3) the presence of a more recent alluvial fill-and a corresponding shorter period of pedogenesis - in the valley axis; or (4) a combination of all these factors.

The character of the basal deposits is also suggestive of at least two alluvial fills in the upland valley. The transition from basal clast-supported gravels on the lower side slopes (e.g., BHT 1 and
BHT 4) to basal clays on the more distal side slopes (e.g., BHT 3) is indicative of a facies change from a channel depositional environment to an overbank environment, while the fining upwards sequences in the overlying deposits are consistent with a single, albeit truncated, suite of alluvial sediments. In contrast, the varying character of carbonate morphology and organic concentration and the abrupt erosional boundary separating the upper clay zones from the basal caliche gravels in BHT 6 and the thinner, roughly equivalent unit in BHT 5 (Zone 2) are strongly suggestive of a second distinct alluvial packet inset into the older Pleistocene deposits. Although no firm data are available, the morphologic and chemical characteristics of the fill make it a very strong possibility that this younger fill is of Holocene age, and therefore has the potential to contain buried archaeological deposits.

However, even though the temporal range represented by the valley axis deposits are consistent with the period of prehistoric human occupation in the region, the characteristics of the sediment are not ideal for preservation of stratified archaeological sites. Although few surface cracks were observed during field work in early February, these deposits are equivalent to the Tobosa vertisol, and the textural characteristics of the sediment make it almost certain that this soil is subject to extensive vertisolic cracking and mixing during the warmer parts of the year. As a result, the context of any archaeological materials contained in the deposit should be considered suspect and examined very closely for stratigraphic integrity. At present, no archaeological materials are known from this sediment body.

Finally, the integrity of all sediments exposed in the present study area have been further compromised to a limited degree by the combined effects of floral and faunal turbation. Of particular note are the actions of shrub roots, ants, and other burrowing insects, and small burrowing animals. However, the combined effects of these agents are probably distinctly secondary to the physical processes of disturbance outlined previously.

\section{CONCLUSION}

In conclusion, a number of specific statements can be make regarding the geomorphic character of the Del Rio landfill expansion site, towit:

(1) The northwestern portion of the study area is characterized by poorly vegetated ground, relatively steep topography, and a number of deeply incised arroyos. As a result, slope wash processes are efficient and extensive; slope wash deposits are 
shallow and localized; and the substrate, consisting either of an indurated calcrete or bedrock, is typically exposed at the surface. Therefore, the potential for buried archaeological materials is poor.

(2) The remainder of the valley side slopes are mantled by approximately $30 \mathrm{~cm}$ of alluvial/colluvial deposits derived primarily from slope wash flowing off the surrounding uplands. Archaeological materials dating back to the Paleo-Indian period are incorporated in the surface mantle, indicating that it has been accumulating for some 5000 years at minimum; however, the overall integrity of the deposit is questionable, and the local context of archaeological materials recovered from this sedimentary body should be closely examined for indications of displacement and reworking.

(3) The slope wash-mantled valley side slopes in the southeastern portion of the study area are underlain by a relatively mature, truncated soil developed in sediments of probable late Pleistocene age. As a result of its apparent antiquity and of the truncation of the A horizon, the probability of incorporated archaeological materials is extremely low, and further testing is not recommended.

(4) The southeastern end of the study area in the valley axis is characterized by up to a meter of alluvial clay of probable Holocene age overlying older alluvial deposits. Therefore, although none are currently known, these deposits have the potential to contain archaeological materials, however, the context of any such remains would be questionable due to the likelihood of extensive argilliturbation of the clay matrix.

(5) The northeastern end of the study area in the valley axis is characterized by a partially dissected gravel surface resulting from erosion of the overlying fines by a headward-trenching arroyo encroaching up valley from the northwest. As a result of the erosion of the fine matrix, the potential for preserved archaeological materials is practically nonexistent.

(6) Although the uplands surrounding the valley are mapped as Uvalde Gravel, examination of the few gravels present on the uplands and the extensive deposits in the valley alluvium reveals a lithologic suite that is composed almost entirely of locally derived limestone. Therefore, the identification of the upland caliche cap as Uvalde Gravel is probably in error and should be reexamined.

\section{REFERENCES CITED}

Barnes, V. E.

1977 Geologic Atlas of Texas. Del Rio Sheet. Bureau of Economic Geology, The University of Texas at Austin.

Barnes, V. E., W. C. Bell, S. E. Claybaugh, P. E. Cloud, Jr., R. V. McGee, P. U. Rodda, and K. Young

1972 Geology of the Llano Region and Austin Area: Field Excursion. Bureau of Economic Geology, The University of Texas at Austin, Guidebook 13.

Birkeland, P. W.

1984 Soils and Geomorphology. Oxford University Press, New York.

Blair, W. F.

1950 The Biotic Provinces of Texas. The Texas Journal of Science 2(1):93-117.

Burkett, R. W.

1990 Archaeological Survey (Phase I) for Proposed Landfill Expansion, City of Del Rio, Val Verde Couny, Texas. Center for Archaeological Research, The University of Texas at San Antonio, Archaeological Survey Report 193.

Folk, R. W.

1980 Petrology of Sedimentary Rocks. Hemphill Publishing Co., Austin, Texas.

Golden, M. L., W. J. Gabriel, and J. W. Stevens 1982 Soil Survey of Val Verde County, Texas. United States Department of Agriculture, Soil Conservation Service, in cooperation with Texas Agricultural Experiment Station and Val Verde County Commissioners Court.

Graham, E. E.

1948 Determination of Soil Organic Matter by Means of a Photoelectric Colorimeter. Soil Science 65:181-183.

Munsell Color

1975 Munsell Soil Color Charts. Macbeth Division of Kollmorgen Corporation, Baltimore, Maryland. 
Natural Fibers Information Center Staff

1987 The Climates of Texas Counties. Natural Fibers Information Center, The University of Texas at Austin.

Olson, G. W., compiler

1976 Criteria for Making and Interpreting a Soil Profile Description: $A$ Compilation of the Official USDA Procedure and Nomenclature for Describing Soils. University of Kansas Publications, Lawrence.

Sellards, E. H., W. S. Adkins, and F. B. Plummer

1932 The Geology of Texas. Vol. I: Stratigraphy. Bureau of Economic Geology, The University of Texas at Austin, Bulletin 3232.

Singer, M. J. and P. Janitzky, editors

1986 Field and Laboratory Procedures Used in a Soil Chronosequence Study. United States Geological Survey Bulletin 1648.

Soil Survey Staff

1951 Soil Survey Manual. United States Department of Agriculture, Handbook 18. Government Printing Office, Washington, D.C.

1988 Keys to Soil Taxonomy. Fourth printing. Soil Management Support Services Technical Monograph 6. Cornell University Press, Ithaca, New York.

Wood, W. R. and D. L. Johnson

1978 A Survey of Disturbance Processes in Archaeological Site Formation. Chapter 9 in Advances in Archaeological Method and Theory, edited by M. B. Schiffer. Vol. 1 . Academic Press, New York. 